\title{
III. ENTREVISTAS
}

\section{Mare Nostrum ENTREvista: Gilberto da Silva FranCiSCO - A Pesquisa Brasileira no Heraion de Delos ${ }^{1}$}

A pesquisa sobre o santuário de Hera (Heraion) de Delos é um dos projetos desenvolvidos no âmbito da EfA. Ela foi iniciada no século XIX e avançou até o século XXI, mas com resultados publicados relacionados prioritariamente à produção de estudos específicos (o conjunto do material cerâmico encontrado no depósito votivo, o grupo de terracotas encontradas no mesmo contexto e em outras regiões do santuário), e poucas interpretações sobre o conjunto visando uma interpretação sociológica do fenômeno religioso ali desenvolvido na antiguidade. A pesquisa foi retomada pela arqueóloga Haiganuch Sarian (membro sênior da EfA) em 1990 e está sob minha responsabilidade desde 2018. O objetivo principal é apresentar um texto sobre a história do culto de Hera em Delos em um volume específico na série Exploration Archéologique de Délos (EAD) e, para tanto, o projeto é desenvolvido em intenso ambiente colaborativo.

Atualmente, a pesquisa é desenvolvida por uma equipe ligada ao grupo de estudos sobre o Heraion de Delos sediado na Unifesp, e as pesquisas arqueológicas são beneficiadas pelo financiamento prioritário da EfA. A formação da equipe contempla pesquisadores de várias universidades brasileiras, ${ }^{2}$ com especialidades diferentes, visando a compreensão de um amplo e variado conjunto documental relacionado a práticas que se desenvolveram do século VIII ao I a.C. (entre os períodos caracterizados como arcaico e helenístico), portanto, em contexto estrutural ou de longa duração. Dessa forma, cabe notar que as informações que apresentarei na sequência são a síntese de ideias de publicações já estabelecidas, sua revisão, novos dados ainda não publicados, e a reflexão conjunta do grupo que venho liderando, seja nas reuniões que temos, atualmente de modo virtual, seja nas atividades de museu, biblioteca e de campo em Delos. Assim, o uso do pronome "nós" é mais que um "nós" majestático, mas a indicação do conhecimento que vem sendo produzido de forma colaborativa. E, com isso, é preciso ressaltar a importância das contribuições da professora Haiganuch Sarian, que não apenas retomou as

\footnotetext{
1 Professor Adjunto da Universidade Federal de São Paulo (Unifesp), Membro Sênior da École française d'Athènes (EfA).

2 A composição do grupo pode ser observada no seguinte link: https://www.unifesp.br/campus/gua/institucional/academico/grupos-de-estudos/2299-grupo-de-estudos-sobre-oheraion-de-delos.
} 
pesquisas sobre o Heraion de Delos em 1990, mas que atuou na revisão de muitas das propostas anteriormente apresentadas e consolidou a participação de pesquisadores brasileiros nesse projeto, seja como colaboradores, seja como estagiários.

\section{Mare Nostrum (Lilian Angelo de Laky e Erica Angliker): Quando começaram as} atividades de culto no santuário de Hera em Delos? Você poderia apresentar um resumo das conclusões sobre as novas propostas de datação do início do culto?

Gilberto da Silva Francisco: Os dados mais recentes relacionados às pesquisas sobre o Heraion de Delos, composto por um conjunto, ainda inédito, de objetos encontrados em escavações arqueológicas ao longo do século XX e XXI, e a partir de dados já publicados, que estão sendo reavaliados, indicam que o início do culto à deusa Hera em Delos teria iniciado no período caracterizado como geométrico recente, entre 750-700 a.C.

Essa referência temporal vem sendo defendida mais recentemente, em oposição à proposta anterior, defendida por Charles Dugas e André Plassart, que situavam o início do culto no século VII a.C., a partir da análise do material cerâmico do depósito votivo, correspondente à primeira fase do culto, que foi encontrado em uma escavação dirigida por Pierre Roussel em 1911, e apresentado parcialmente em publicações da EfA de 1928, por Dugas e Plassart, respectivamente, Les Vases de l'Héraion (EAD 10) e Les Sanctuaires et les cultes du Mont Cynthe (EAD 11).

Antes disso, houve algumas intervenções. O próprio Roussel empreendeu uma delas em 1909, e é digno de nota algumas outras na segunda metade do século XIX, empreendidas por L. Terrier, A. Lebègue, M. Stamatakis, Th. Homolle e A. Hauvette. Entretanto, foi apenas em 1911, que o depósito votivo foi encontrado, quando Roussel aprofundou a escavação da cella do templo $\mathrm{B}$, e encontrou o templo $\mathrm{A},{ }^{3} \mathrm{o}$ mais antigo, e o material correspondente à primeira fase do culto no Heraion de Delos. Assim, depois da análise desse material em 1912, o conjunto de oferendas e suas especificidades começavam a ser mais bem compreendidos, inclusive a cronologia do início do culto.

$\mathrm{O}$ autor que discutiu com mais profundidade esse material foi Dugas (EAD 10), que defendia o início do culto no século VII a.C., já que o conjunto mais expressivo e mais antigo encontrado no depósito votivo era aquele caracterizado pela cerâmica orientalizante. No mesmo depósito, foram encontrados alguns objetos cerâmicos correspondentes ao geométrico recente,

\footnotetext{
${ }^{3}$ Para a situação dos elementos construídos e sua distribuição em fases de ocupação do santuário, ver fig. 2. 
portanto anteriores ao século VII a.C., mas em menor número, o que foi interpretado por Dugas como material remanescente de atividades anteriores ao culto. Segundo ele, a região teria sido ocupada desde o geométrico recente, mas o culto só teria começado efetivamente depois. Essa interpretação orientou as narrativas sobre o culto de Hera em Delos e temas associados (como a própria cronologia inicial do templo A), apesar de algumas indicações ao material do geométrico recente em determinadas publicações.

Entretanto, ao longo do século XX e XXI, algumas novas escavações e a reavaliação do material do depósito votivo permitiu recuar um pouco mais a cronologia inicial do culto de Hera em Delos, incluindo o material correspondente ao geométrico recente nas práticas cultuais ali desenvolvidas. Por exemplo, na escavação empreendida por Jean Ducat em 1964, foram encontrados fragmentos de cerâmica geométrica no terraço ao lado dos templos na região de alguns muros que ele escavou parcialmente, informação que foi reportada no Bulletin de Correspondance Hellénique (BCH) e que foi incluída timidamente no Guide de Délos (GD).

Em 2008, na escavação dirigida por Haiganuch Sarian, um conjunto expressivo de material do geométrico recente foi encontrado associado a um dos muros parcialmente escavados por Ducat, que, em 2008, foram integralmente escavados até sua base, consolidando a ideia de que aquela estrutura teria sido construída antes do século VII a.C. Além disso, a reavaliação do material geométrico encontrado no depósito votivo, que, segundo Dugas, não teria relação com o culto de Hera, indicava outra situação. Por exemplo, o exame mais detido de uma parte dele, 5 modelos cerâmicos de romã (ver figura 1), apontam para um tipo de objeto muito claramente integrado ao culto de Hera desde o período geométrico.

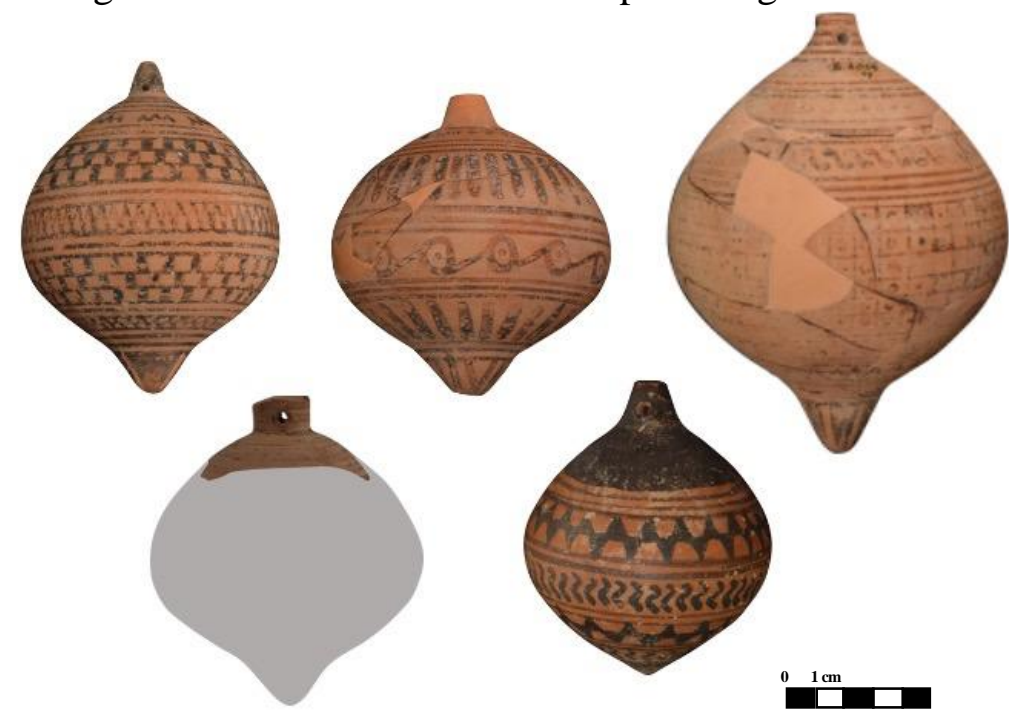

Figura 1: Modelos de romã em terracota datados do geométrico recente encontrados no depósito votivo do Heraion de Delos (autora: Carolina Machado Guedes a partir do programa Metashape Agisoft). 
Em outros santuários da deusa, especialmente até o século VI a.C., modelos de romãs e a própria fruta foram oferecidos, o que nos revela uma forte possibilidade de que, em Delos, já no século VIII a.C., o culto à deusa teria começado; e que, no século VII a.C., ele teria sido ampliado. Assim, diferente de um início do culto no século VII a.C., pensamos que, nesse século, era iniciada uma fase de ocupação mais consistente do santuário, mas não o início do culto de Hera, que, em Delos, já era existente. Outros elementos também contribuem para essa interpretação de uma cronologia mais recuada do início do culto, tais como as formas de preservação do material do depósito votivo e a lógica da organização desse conjunto feita pelos antigos.

Quanto à preservação dos objetos, é importante notar que os mais antigos, conforme indicado, são datados do geométrico recente, objetos que já tinham mais de 200 anos quando o depósito votivo foi reunido. Se seu uso fosse desconectado do culto, portanto, não correspondentes ao conjunto de oferendas feitas à deusa, eles não teriam sido preservados no interior do templo, mas em situação menos protegida. Esses objetos utilizados em contextos menos perturbados, como contexto funerário ou ritualístico, tendem a ser preservados de forma diferente.

A maior parte dos objetos associados aos elementos arquitetônicos ou no próprio terraço, cujo uso estava relacionado ao santuário, mas não foram preservados no interior do templo, chegaram até nós bastante fragmentados. Geralmente, são pequenos fragmentos isolados, situação muito diferente do conjunto preservado no interior do templo que foi organizado como um conjunto no depósito votivo. A qualidade de preservação desses objetos é, de maneira geral, muito boa. No caso dos modelos cerâmicos de romã, por exemplo, além da boa preservação externa e pouquíssima fragmentação, um deles preservou alguns pequenos elementos internos, o que permitiu identifica-lo, inclusive, como um instrumento musical (uma espécie de chocalho). Assim, parece que esse conjunto de vasos do geométrico recente foi preservado no interior do templo e integrado ao conjunto de oferendas que crescia ao longo do tempo e não fora desse contexto, como remanescente de atividades anteriores e desconectadas do culto.

Ainda sobre o estado de fragmentação dos vasos de cerâmica do geométrico recente no depósito votivo, alguns deles, fragmentados, foram remontados e restaram poucas lacunas, o que permite observar as suas feições originais; diferente da maior parte dos fragmentos encontrados nas escavações dos elementos externos aos templos, que, geralmente, são pequenos fragmentos isolados, o que impede sua remontagem. Isso tudo indica que houve efetivamente 
diferentes processos que incidiram sobre tais objetos ao longo do tempo. Aqueles que foram preservados no interior do templo e depois reunidos no deposito votivo são caracterizados por um grau de preservação mais amplo; seja aqueles que não foram fragmentados, seja aqueles cuja fragmentação preservou o conjunto de vestígios de um mesmo objeto, permitindo a sua remontagem.

Por fim, ainda, é importante notar que, no momento de criação do depósito votivo, quando o templo mais antigo, o templo A, foi parcialmente destruído, e o templo B, o mais recente, foi construído sobre ele, a aglutinação das oferendas da fase anterior foi muito possivelmente feita a partir do reconhecimento dos responsáveis pelo santuário como um conjunto. Ou seja, foram os próprios antigos que, no século V a.C., reconheceram a unidade de grupo de objetos, o que desabona em grande medida a interpretação de que tais objetos do geométrico recente encontrados no depósito votivo teriam sido correspondentes à ocupação da região antes do estabelecimento do culto de Hera.

Mare Nostrum (Laky e Angliker): O Heraion passou por várias fases de construção. Quais são as principais fases do santuário?

Francisco: Antes da apresentação das construções do Heraion de Delos, é preciso dizer algo sobre a terminologia que propomos para a identificação de alguns dos elementos do santuário. De maneira geral, a bibliografia utiliza o termo Heraion para descrever tanto o santuário (o complexo paisagístico-religioso) como os templos (um tipo de construção específica). Como há bastante variedade desse uso no que se refere à caracterização do Heraion de Delos, propomos, aqui, a delimitação do termo Heraion para a caracterização do hieron (a unidade sagrada), cuja delimitação espacial é o tememos.

Considerando isso, identificamos três fases de organização do espaço do santuário, que chamamos de Heraion I, II e III (ver fig. 2). Diferente disso, os dois templos, cuja construção foi subsequente (o primeiro datado de 750-700 a.C., e o segundo datado provavelmente do primeiro quartel do século $\mathrm{V}$ a.C.), chamamos, respectivamente, de templo A, o mais antigo, e templo B, o mais recente. Utilizarei, dessa forma, para a apresentação do espaço do santuário que mudou significativamente no longo recorte temporal relacionado ao funcionamento do santuário, os termos Heraion I, II e III para caracterizar as três principais fases de organização do espaço. 

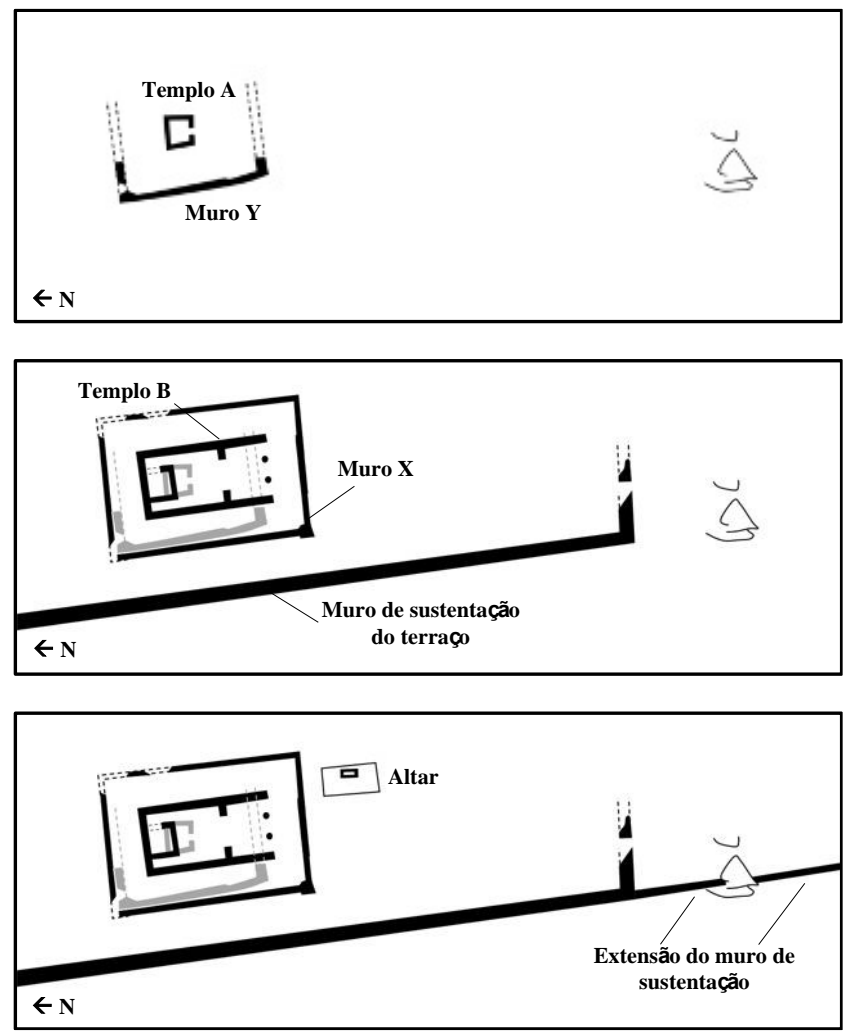

Figura 2: Fases de ocupação do santuário: a. (acima) Heraion I (século VIII-V a.C.); b. (meio) Heraion II (século V-IV a.C.); c. (abaixo) Heraion III (século IV ao I a.C.) (autor: Gilberto Francisco).

\section{Heraion I}

A primeira fase marca a instauração do culto de Hera em Delos já na segunda metade do século VIII a.C. e durou até o primeiro quartel do século V a.C. Assim, um período de, pelo menos 200 anos. Nela, as construções conhecidas são simples e poucas: trata-se de uma capela e um muro associado a ela parcialmente escavado, cuja função ainda não é muito clara (pensase na possibilidade de ele ter sido um muro que estruturava um pequeno terraço relacionado à capela, ou ainda um períbolo que delimitava o espaço do santuário naquele período.

A posição do santuário é próxima do monte Cinto (no seu sopé), para onde ele estava orientado; ou seja, o santuário era voltado para o sul, estabelecendo-se uma conexão entre ele e o monte Cinto. O terreno apresenta uma leve inclinação e, nesse sentido, pode ter havido a necessidade de certa correção, o que pode ter sido sanado com a construção de um pequeno terraço talvez associado ao muro citado, atualmente chamado de muro Y, de cerca de 14 metros na sua extensão na região oeste do terraço. Sobre ele, foi construída a capela, o templo A, cuja forma é trapezoidal, e medindo, no comprimento e largura máximos, 3,4 x 2,87 metros (ver fig. $2 b, 3$ e 4$)$. 

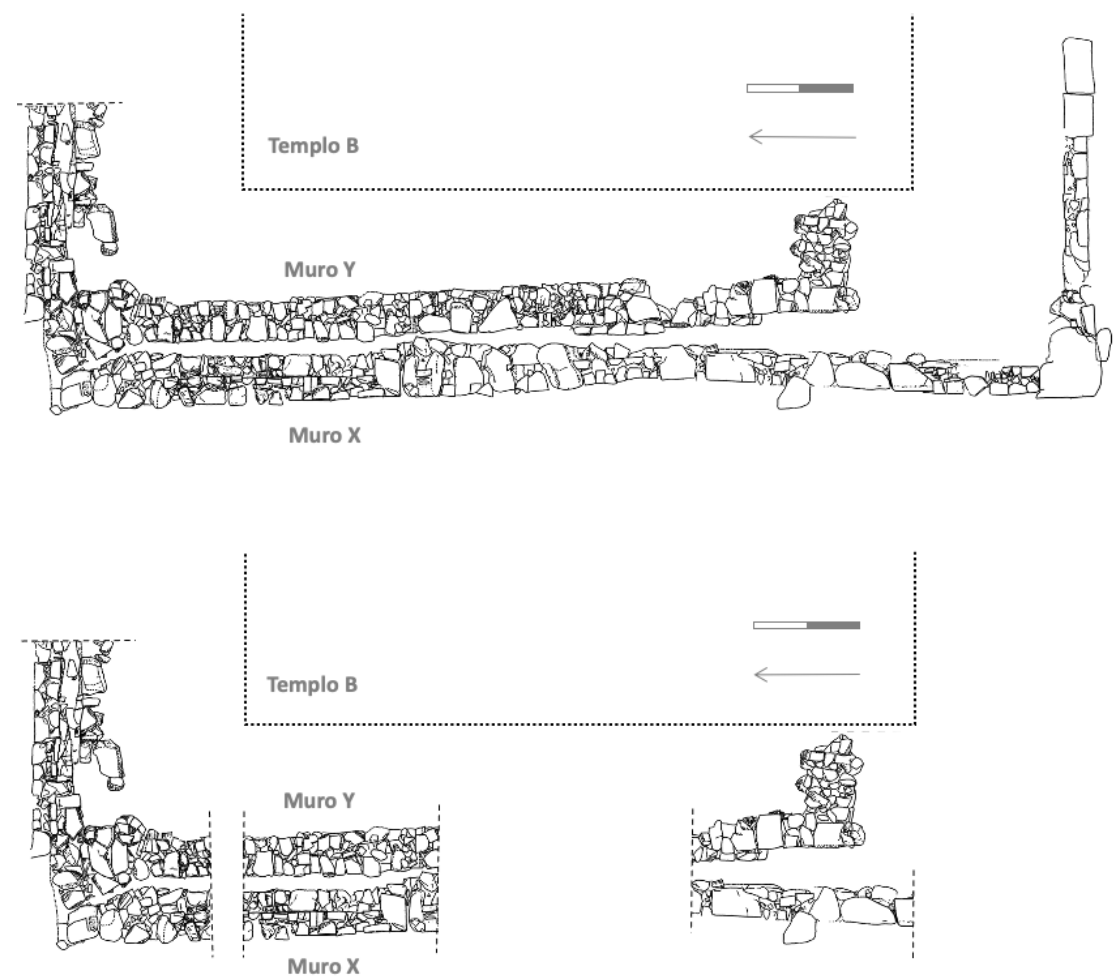

Figura 3: Planta dos Muros X e Y: a. (acima) Extensão dos muros em escavação por Sarian (2008); b. (abaixo) Indicação dos trechos escavados por Paul Bernard (1958) e Jean Ducat (1964).

A parte que foi preservada é constituída por certa elevação das paredes (ver fig. 4) e, no interior, uma banqueta que domina toda a parte posterior da construção (onde, possivelmente, fosse depositada boa parte das oferendas), que é organizada por pedras de gnaisse. Ao lado dele, foi escavado o muro $\mathrm{Y}$, cuja cronologia foi baseada nos achados cerâmicos (consistentemente situados no período geométrico), indicado a contemporaneidade do templo e do muro, que poderia ser uma espécie de períbolo e/ou de sustentação de um pequeno terraço.

A cronologia dessas duas construções é baseada no material encontrado no depósito votivo e no próprio muro, datados do geométrico recente. Assim, nessa primeira fase, pensa-se que a criação do santuário materializou um pequeno conjunto arquitetônico, muito possivelmente conectado ao monte Cinto, cuja ocupação parece ter durado, pelo menos, 200 anos, alcançando o primeiro quartel do século V a.C., referência cronológica indicada pelo material mais recente encontrado no depósito votivo, um representativo grupo de cerâmica ática, que foi datada inicialmente no século VI, mas, em algumas publicações mais antigas, já havia a sugestão de que parte desse material fosse correspondente à produção ática do início do século V a.C.; talvez, meados do século V a.C. 


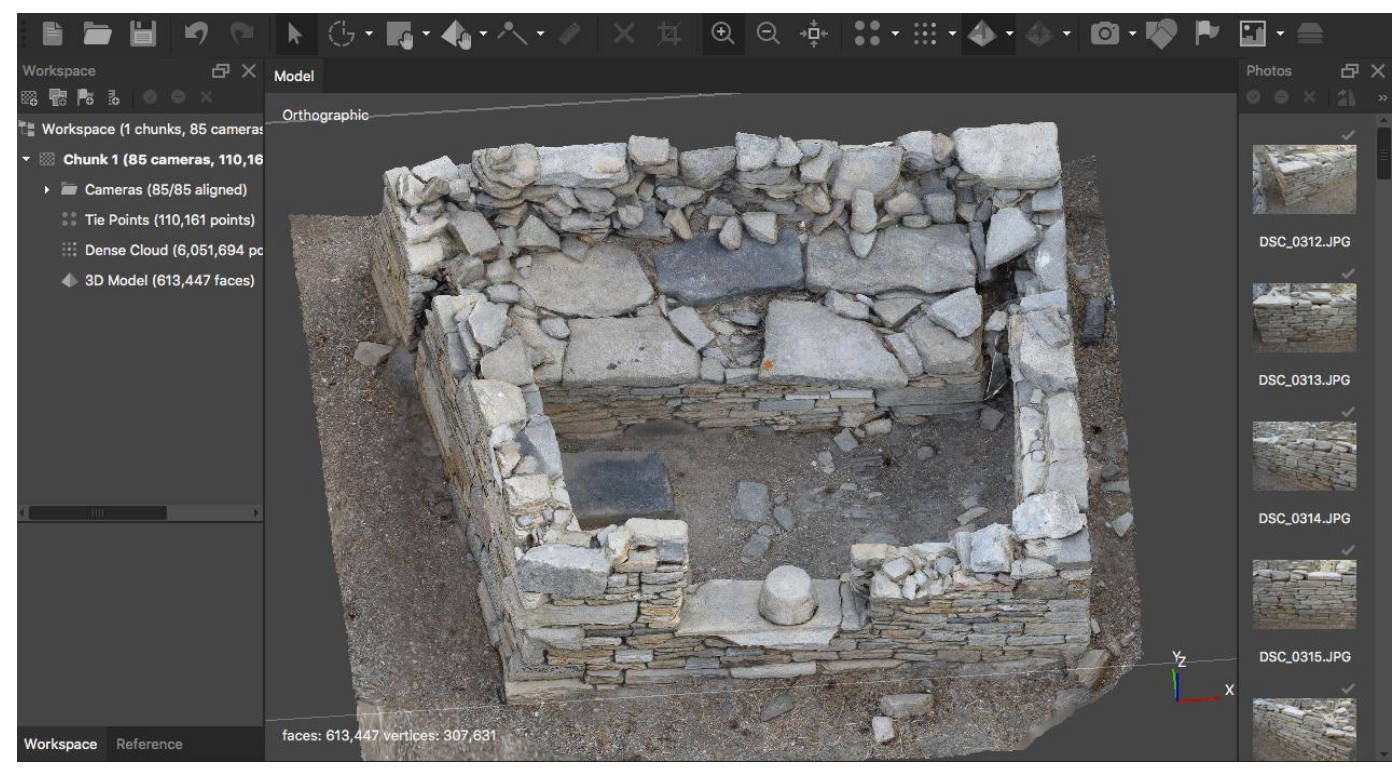

Figura 4: Imagem a partir de modelo 3D das ruínas do templo A (autora: Carolina Machado Guedes a partir do programa Metashape Agisoft).

\section{Heraion II}

A segunda fase de ocupação do santuário apresenta uma significativa modificação do espaço. Além de uma grande ampliação do terraço, construiu-se um novo templo (o templo B), mais amplo e já ligado às perspectivas mais padronizadas da arquitetura grega: trata-se de um templo dórico distilo in antis, cujas medidas mais amplas têm cerca de 13 metros de comprimento e 6,9 metros de largura, construído com blocos de mármore de, pelo menos, duas origens diferentes, com uma planta caracterizada pela presença de um pronaos e uma cella (ver fig. $2 b, 5$ e 6$)$.

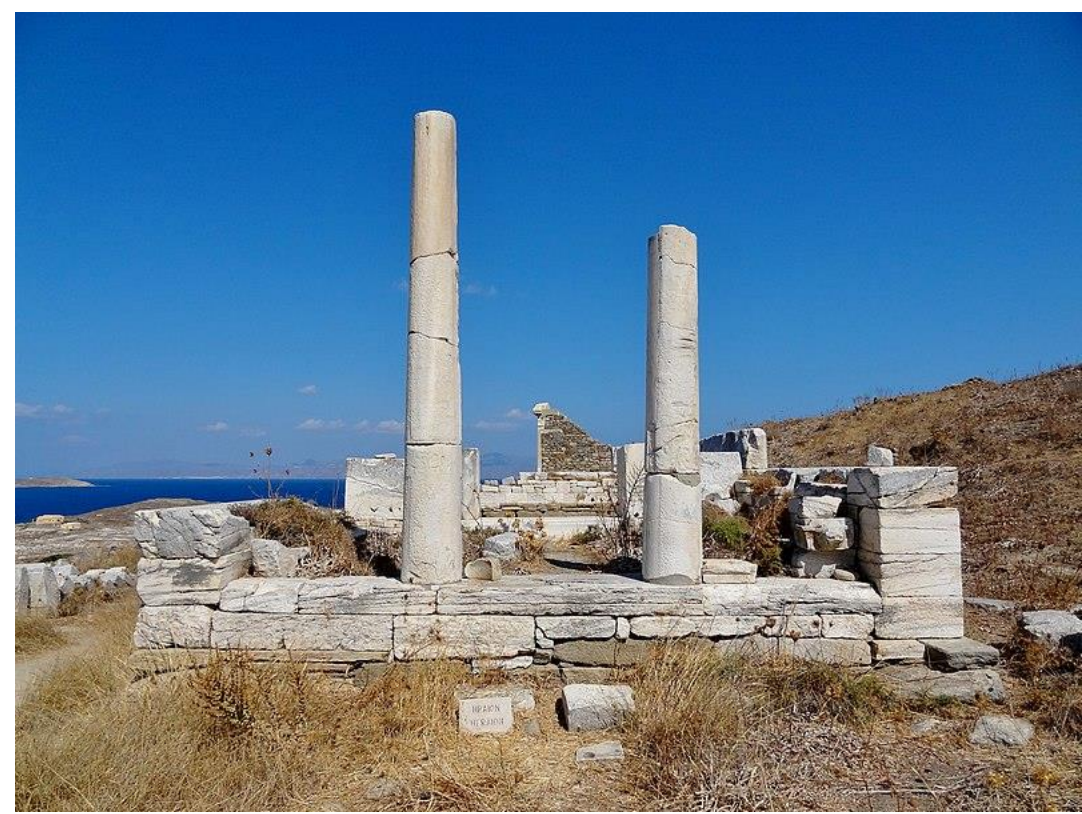

Figura 5: Fotografia da fachada principal do templo B (arquivo pessoal) 


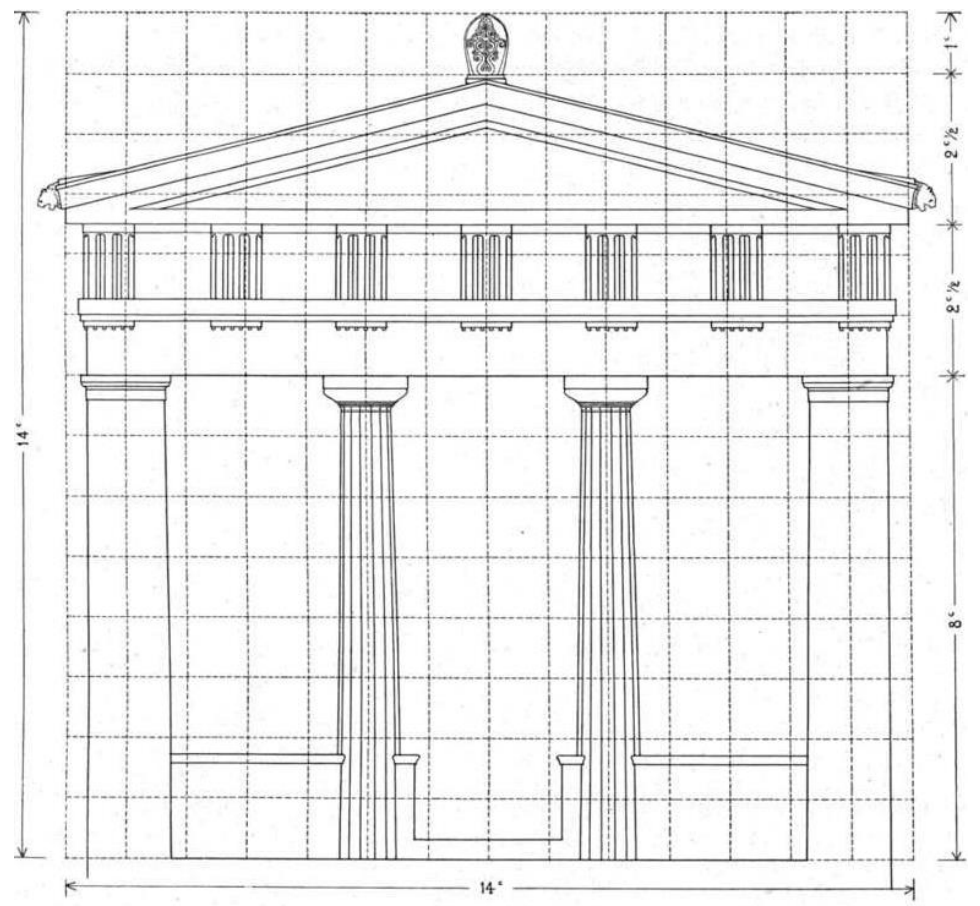

FACE SUD

Figura 6: Fachada principal - proposta de reconstituição (extraído de Plassart, EAD 11).

O início dessa segunda fase está conectada ao fim do culto na paisagem anterior, que foi amplamente destruída e os elementos arquitetônicos soterrados com as oferendas aglutinadas, o que nos coloca o primeiro quartel do século $\mathrm{V}$ a.C. (ou um pouco depois) como referência para a sua construção. Além disso, a ampliação do terraço demandou a construção de um grande muro (cerca de 64 metros de comprimento) de sustentação na parte com inclinação mais aguda do solo natural a oeste; e, nesse contexto, a projeção do terraço passava a alcançar a região próxima de um conjunto de rochedos, onde havia uma fonte e a escadaria de acesso ao topo do monte Cinto. Dessa forma, estabeleceu-se uma conexão explícita entre os espaços do santuário de Hera e de Zeus.

Sobre o templo, é preciso dizer que há uma série de elementos específicos, que não podem ser claramente situados nessa fase de sua construção, mas também poderiam ser relacionados a reformas posteriores. De qualquer forma, é importante citar que havia, no pronaos, uma sequência contínua de baquetas contíguas às paredes; associados às colunas e antae, há alguns elementos que indicam a anexação muito possível de grades e portas de material metálico; na cella, havia um solo composto por um mosaico de pequenos seixos rolados, sobre o qual estava situada uma base de estátua de culto, que ainda será descrita mais detalhadamente.

A fundação do templo B é relativamente alta, o que indica alguma referência da situação do solo do terraço na época de sua construção. Mais que isso, há mais um elemento que poderia 
estar conectado a esse conjunto: trata-se de um muro (o muro X), circundando todo o templo, que foi interpretado, durante bastante tempo, como um muro de períbolo. Essa interpretação apresenta dois problemas significativos: o primeiro é a proximidade do muro em relação às paredes do templo B, o que não se justifica considerando o amplo espaço do novo terraço; e a própria situação externa de um altar que seria construído no final do século IV a.C.

Diferente disso, a revisão dessa interpretação sugere outra possibilidade: em vez de um muro de períbolo muito próximo do templo B, esse muro poderia ser a fundação de uma espécie de plataforma que esconderia a fundação do templo B com pedras irregulares e, além disso, permitia um melhor acesso ao interior desse edifício. Dessa forma, a segunda fase pode ser pensada pela intensificação do culto que teria demandado a construção de um santuário mais amplo. Essa ampliação ratificou a associação com o monte Cinto já que a projeção do terraço delimitava uma entrada para dois santuários. Além disso, o novo templo integrava o culto de Hera às tendências da época do ponto de vista arquitetônico, o que fica claro dada a construção do templo dórico in antis.

Há, ainda, um elemento importante e digno de nota: após a construção do novo templo no início do período clássico, aparentemente o santuário foi abandonado. Essa interpretação está baseada na lacuna de material entre a primeira metade do século V a.C. e o final do século IV a.C., quando a nova fase de ocupação do santuário foi iniciada; o que sugere a ausência de frequentação do santuário nesse período. De fato, é complicado interpretar essa lacuna, que vem sendo pensada como abandono, mas essa interpretação deve ser aprofundada, considerando o contexto deliano de forma mais ampla.

\section{Heraion III}

Essa última fase pode ser situada entre o final do século IV a.C. e o abandono do santuário, talvez, no século I a.C. Nela, podem ser observadas algumas modificações no templo B, o que ainda não é muito claro, e outros elementos fundamentais: a inserção de um altar jônico sobre um conjunto de degraus (uma espécie de plataforma) situado lateralmente diante da fachada principal do templo B e a ampliação do complexo da entrada do santuário (ver fig. 2c e 7).

Sobre o altar, um paralelo em Delos indica um referencial cronológico importante: tratase do altar bastante parecido do Afrodision de Stesileos, datado do final do século IV a.C. Além da referência cronológica relacionada à época de construção desse santuário, o altar helenístico do Heraion de Delos apresenta alguns encaixes de grampos em "duplo T", característicos da 
produção arquitetônica da época. Parece que esse altar é datado do final do século IV a.C., o que nos apresenta um significativo referencial cronológico para situar essas novas intervenções no Heraion.

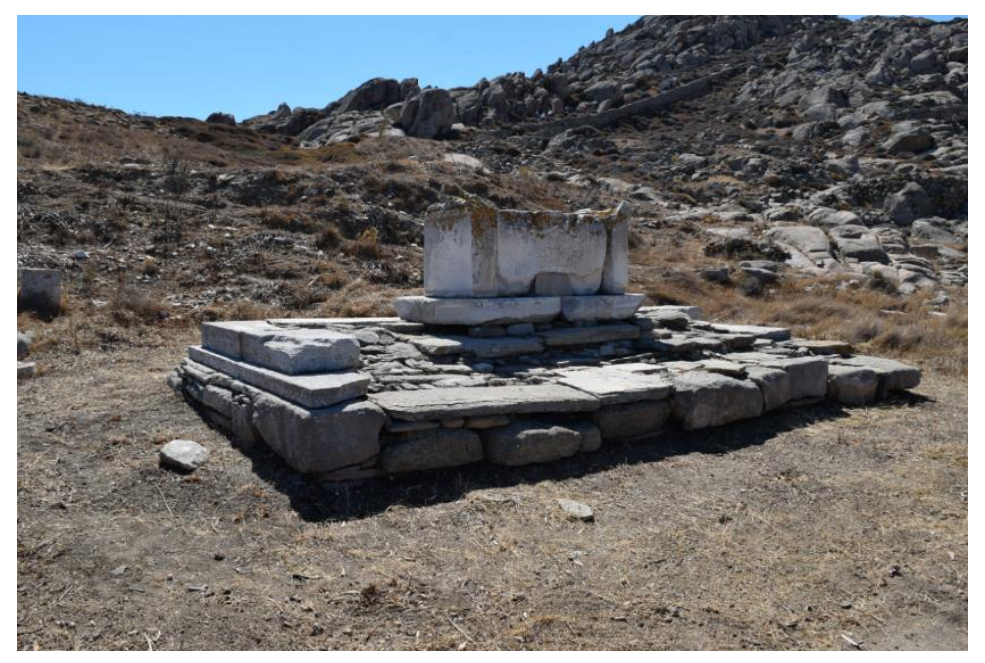

Figura 7: Fotografia das ruínas do altar, 2018 (arquivo pessoal).
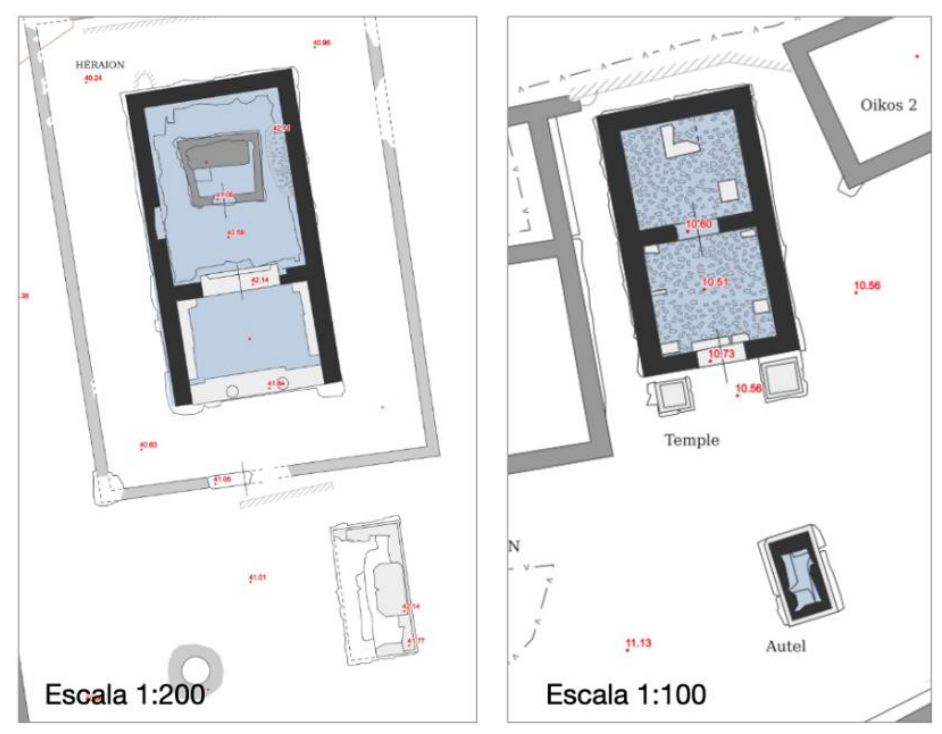

Figura 8: Situação do Heraion (esquerda) e do Afrodision (direita) de Delos (extraído do WebSig Delos e adaptado). ${ }^{4}$

Tendo ainda o Afrodision como referência, é importante notar que não apenas o altar, mas o conjunto templo e altar indicam outros paralelos como o Heraion de Delos: o templo possui planta bastante parecida com o templo B do Heraion, possuindo as banquetas no pronaos

\footnotetext{
${ }^{4}$ Para o WebSig Delos, acessar o link https://sig-delos.efa.gr/
} 
inclusive; e, além da similaridade desses altares, a posição relacionada aos templos é a mesma: eles são posicionados lateralmente diante dos templos (ver fig. 8).

Ainda, a orientação desses templos é quase a mesma. Ou seja, parece que houve certo interesse em emular alguns aspectos de um santuário já tradicional quando o Afrodision foi construído, o que foi expressado nessas semelhanças. Assim, a observação do Afrodision pode ajudar a compreender as dinâmicas desenvolvidas no Heraion no período helenístico.

Quanto à extensão do muro de cerca de 20 metros associado à entrada sul, que reorganizou a entrada do terraço do Heraion, ela pode ser compreendida tendo como referência a criação de outro santuário: o Serapeion, santuário construído no século II a.C. Quando ele foi construído, o terraço do Heraion já era antigo e abrigava as atividades relacionadas ao culto de Hera em uma perspectiva tradicional. Nesse sentido, na organização do espaço desse santuário, foi aproveitado o grande muro de sustentação do terraço do Heraion. O muro deixava se ser exclusivamente ligado ao Heraion e passava a ser elemento fundamental da organização do temenos do Serapeion.

Foi, justamente respondendo à organização do espaço nesse novo santuário, que a extensão do muro anterior foi empreendida, considerando que o espaço foi projetado para além da delimitação final do muro de sustentação do Heraion. Assim, do ponto de vista da paisagem e do programa arquitetônico, o espaço do culto de Hera foi afetado pelas atividades do culto que começou a ser desenvolvido ao lado (ver fig. 9).

Esse muro foi escavado em 2006 em alguns trechos e o material associado a ele é prioritariamente do período helenístico, o que reforça a defesa de sua cronologia situada no período helenístico e a associação à espacialização do Serapeion. Entretanto, para uma compreensão mais bem definida desse cenário, é necessário aprofundar o estudo do conjunto de cerâmica helenística ali encontrado, o que poderá oferecer um maior detalhamento cronológico.

Nesta última fase de ocupação do santuário, o Heraion III, nota-se que o culto ainda era importante na medida em que um novo altar foi instalado e algumas possíveis reformas foram empreendidas no templo B além da reorganização do terraço com alguma possível relação com a criação do Serapeion. Algo dessas reformas foram indicadas em algumas inscrições desse período, o que ainda será comentado. 
Mare Nostrum (Laky e Angliker): É possível comentar algo sobre o culto praticado no Heraion a partir dos objetos votivos?

Francisco: Em primeiro lugar, é preciso dizer que uma caracterização detalhada do culto de Hera em Delos não é possível de ser empreendida. As fontes conhecidas não possibilitam, por exemplo, a compreensão de aspectos específicos da natureza da divindade, do regime de oferendas em toda a duração do culto, da reprodução das práticas cultuais e dos elementos litúrgicos próprios desse culto. As hipóteses que foram defendidas ao longo do tempo repousam em aspectos generalistas; e será, nessa direção, que serão apresentados os objetos votivos mais significativos para a compreensão geral do culto de Hera em Delos.

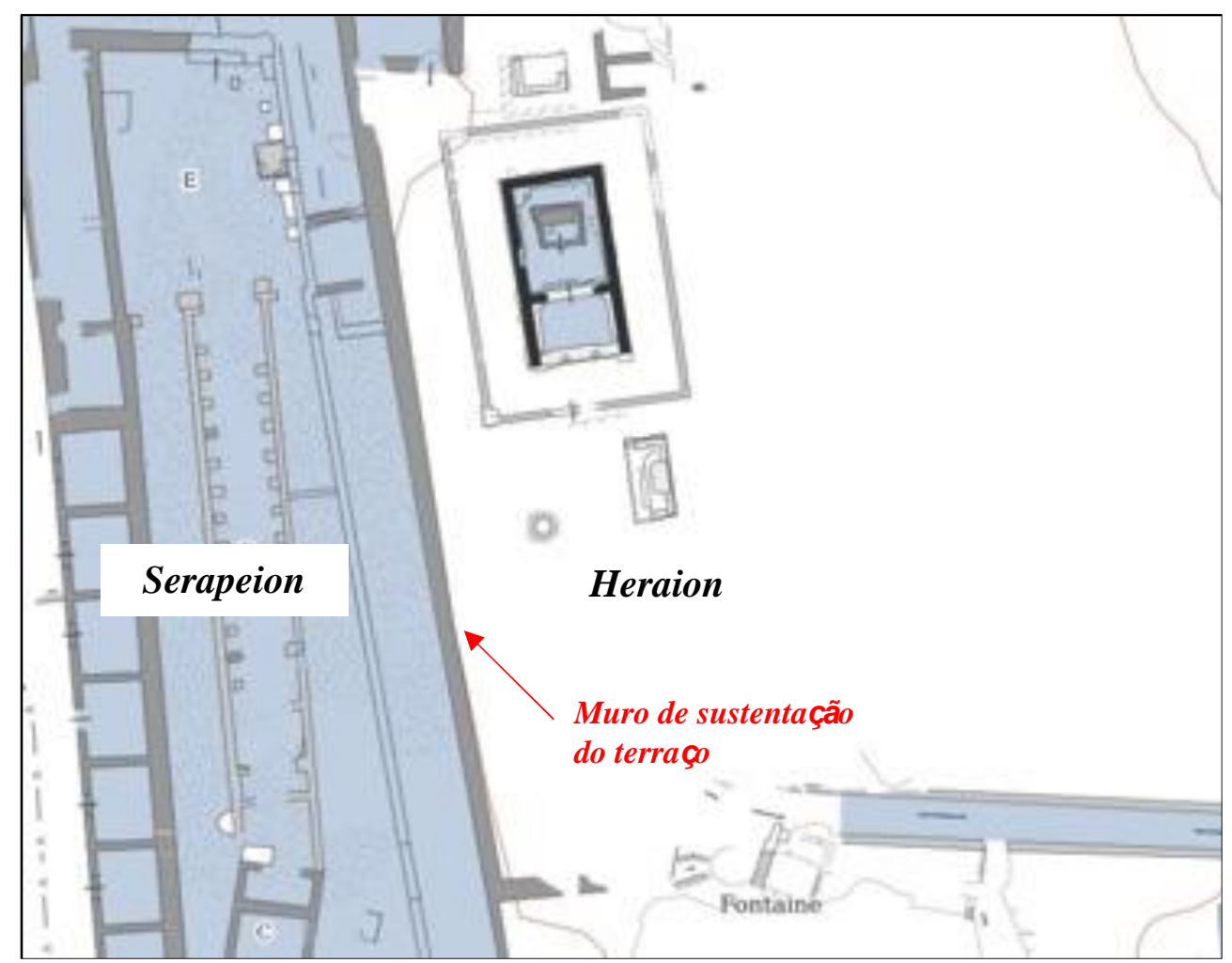

Figura 9: Situação do Heraion e do Serapeion (extraído do WebSig Delos e adaptado).

Os objetos votivos conhecidos do Heraion de Delos são, na sua grande maioria, relacionados à primeira fase do culto e foram preservados por conta de sua aglutinação em um depósito votivo, que é interessante descrever de maneira geral. Como dito, na transição da primeira para a segunda fase de organização do espaço do santuário, o templo A foi destruído, mas foi mantida parte dele, onde foram aglutinados os objetos relacionados às práticas cultuais ali desenvolvidas entre a segunda metade do século VIII ao início do século V a.C. Sobre esse conjunto constituído pelas ruínas do templo A e pelo conjunto de oferendas, foi construído o 
templo B. Assim, do século V a.C. até o ano de 1911, esse complexo caracterizado por um espaço delimitado pelas ruínas de uma antiga construção, que acolhia um grande conjunto de objetos de natureza variada, foi mantido intacto.

Desse conjunto, os objetos votivos relacionados ao culto de Hera, boa parte foi publicada, principalmente o grupo de quase 700 vasos de cerâmica e de centenas de estatuetas de terracota, e foi a partir deles que boa parte das interpretações sobre esse culto foi desenvolvida. Por exemplo, entre as publicações de Dugas e Plassart (EAD 10 e 11), observa-se a apresentação de um conjunto variado de vasos de cerâmica produzidos do período geométrico até o início do período clássico empreendida por Charles Dugas (EAD 10), que não chegou a desenvolver interpretações mais aprofundadas sobre sua natureza cultual. De fato, há algumas interpretações pouco profundas sobre o culto espalhadas na publicação, que desenvolveu prioritariamente uma consistente discussão sobre a tipologia dos vasos de cerâmica.

Já na publicação de André Plassart (EAD 11), apesar de a apresentação da documentação ser menos sistemática (não há um catálogo por exemplo), há uma discussão mais interpretativa das características do conjunto arquitetônico e dos objetos de outra natureza; assim, algumas características do culto aparecem de forma mais desenvolvida na obra de Plassart. Foi, entre a obra de Dugas (um catálogo sistemático), de Plassart (uma interpretação do conjunto) e ainda da publicação de Alfred Laumonier (EAD 23), que alguns elementos do culto passaram a ser definidos.

Por exemplo, a lógica da fertilidade associada a Hera e as comparações com outras manifestações similares em outros santuários da deusa a partir da apresentação dos modelos de romã já apareciam nessas publicações. Além disso, o conjunto de inscrições dedicatórias presentes no material do depósito votivo são apresentadas em uma perspectiva interpretativa. Aliás, é importante dizer que foi justamente a partir dessas inscrições que o próprio santuário foi identificado como um Heraion, na medida em que o nome da deusa aparece em alguns vasos de cerâmica e um fragmento de máscara de terracota encontrados no depósito votivo em 1911.

Antes disso, pensava-se na possibilidade de aquele santuário ser relacionado ao culto de Ísis ou Serápis, já que havia inscrições encontradas próximas dele que apresentavam o nome dessas divindades (hoje, sabe-se que tais inscrições são provenientes do Serapeion, santuário que foi construído ao lado do terraço do Heraion no período helenístico); e outros pensavam, ainda, que poderia se tratar de um santuário de Apolo ou da Deusa Mãe. Mas, mesmo antes do depósito votivo ter sido encontrado, o achado de algumas estatuetas femininas de terracota nas 
intervenções até 1909 indicavam que o culto ali estabelecido seria, muito possivelmente, relacionado a uma divindade feminina, o que foi confirmado depois dos achados de 1911.

O conjunto amplo de objetos do depósito votivo apresenta algumas oferendas específicas, como no caso dos modelos de romãs, mas também alguns vasos como lebes gamikos, um tipo de vaso associado ao casamento. Além disso, Dugas defende a associação de vários vasos de perfumes (aríbalos e alabastros coríntios) ao universo feminino, já que seriam vasos relacionados a perfumes, ou seja, ligados à toalete feminina. Mas, apesar de essa interpretação não ser muito segura, é preciso prestar um pouco mais de atenção em seu argumento.

No grupo de 683 vasos do depósito votivo repertoriados por Dugas (que não representam o conjunto completo, mas sua maioria), as formas mais presentes são de vasos relacionados aos perfumes: da cerâmica produzida por oficinas em Corinto, a mais representativa do ponto de vista quantitativo, há, do chamado estilo coríntio, 179 aríbalos globulares, 26 aríbalos com base circular, 17 aríbalos com base estreita e 88 alabastros; além de 2 aríbalos globulares e 16 com base circular do estilo proto-coríntio. Esses vasos correspondem a quase metade dos vasos publicados por Dugas: cerca de $48 \%$ do conjunto. E, se considerarmos as formas mais representativas quantitativamente de maneira isolada, os aríbalos globulares coríntios representam cerca de $26 \%$ do conjunto; enquanto os alabastros coríntios, $13 \%$. A questão, dessa forma, é diretamente ligada à interpretação dessas quantidades.

Percebe-se, nesse caso, uma forte presença de formas de vasos relacionadas ao uso de perfume, que podem ser conectadas de maneira abstrata ao universo feminino dado o uso, não exclusivo, mas consistente, no âmbito da toalete feminina. Como interpretar essa conexão? Em primeiro lugar, é preciso notar que não houve, até o momento, exames relacionados aos micros vestígios de conteúdos que poderiam ser preservados; no caso, o óleo perfumado. Entretanto, independente da presença do perfume, a forma, em si, já poderia estabelecer essa conexão entre o seu conteúdo tradicional, sua situação de uso e, ainda, as conexões com o universo feminino.

Mas, essas conexões são frágeis. É preciso notar que, no conjunto, os vasos protocoríntios e, principalmente, os vasos coríntios do depósito votivo, para além das formas relacionadas a perfumes, representam cerca de $58 \%$ do conjunto de vasos de cerâmica ali imobilizados. Considerando isso, vale perguntar: qual o significado dessas quantidades bastante consistentes? É bastante claro que, no século VII a.C., a cerâmica coríntia teve sua produção e distribuição mediterrânica intensificada; o que pode ser verificado de forma específica também no conjunto do depósito votivo do Heraion de Delos. Assim, qual seria o significado dessa forte presença: uma adequação à especificidade do culto de Hera em Delos indicado pelos vasos de 
perfume ali imobilizados na dinâmica do culto ou apenas um reflexo de um fenômeno mais amplo relacionado à grande distribuição da cerâmica coríntia, que proporcionou uma maior oferta de vasos produzidos em Corinto inclusive na região da Cíclades?

Dessa forma, parece que o conjunto de vasos de cerâmica, apesar de muito expressivo no depósito votivo, não indica forte especificidade no conjunto. Diferente disso, ela parece apresentar alguns elementos próprios do culto de Hera de forma limitada, e um grupo de oferendas que poderiam ser ofertadas a Hera, mas também a outras divindades.

Além das centenas de vasos de cerâmica, outro grupo específico de objetos encontrados no depósito votivo são estatuetas e máscaras de terracota. A maior parte delas representa figuras femininas, cuja interpretação ainda merece atenção no escopo do nosso projeto. Dentre elas, um grupo expressivo de figuras femininas sentadas e, em alguns casos, pode-se dizer entronadas. Entre elas, há uma estatueta específica que representa um casal sentado, que pode ser interpretado como um casal genérico ou o próprio hieros gamos, Zeus e Hera. Mas, para desenvolver um pouco mais a interpretação sobre seus significados, é preciso considerar os problemas metodológicos relacionados à lógica dessas estatuetas de terracota em contexto votivo.

No caso daquelas encontradas no Heraion de Delos (seja um grupo menor de terracotas encontradas em escavações do terraço, seja o grande grupo que foi encontrado no depósito votivo), a maior parte delas femininas, foram interpretadas por Pierre Lévêque (Héra et le lion, d'après les statuettes de Délos, 1949) e André Plassart (EAD 11) como representações de Hera; o que foi rediscutido na publicação específica de Laumonier (EAD 23), que dedicou uma parte específica para as estatuetas jônicas encontradas no depósito votivo do Heraion de Delos. De forma sintética, apesar de haver boa possibilidade de várias delas terem sido, de fato, representações de Hera, há dúvidas de interpretação; segundo ele, elas poderiam representar a própria deusa, uma sacerdotisa ou a ofertante. Além disso, podemos considerar, em alguns casos, o fenômeno caracterizado por Brita Alroth (Greek gods and figurines: aspects of the anthropomorphic dedications, 1989) como "deuses visitantes".

A própria lógica da representação, se considerarmos que determinadas estatuetas sejam representações de Hera, pode ser discutida. Seriam esses objetos de terracota produzidos originalmente com esse conteúdo; ou seja, no contexto da produção já haveria o interesse de 
criar estatuetas que representassem especificamente a deusa Hera? Ou, diferente disso, um tipo iconográfico de significado mais abrangente e abstrato poderia ser associado, a partir de sua contextualização no culto relacionado a Hera e, nesse sentido, passaria representar a deusa? Há, relacionado a isso, alguns elementos específicos que sugerem uma intenção mais clara de identificação com Hera como, por exemplo, a posição sentada, mais especificamente, entronada; o que aparece de forma consistente na sua caracterização literária; mas, cabe lembrar, esse não é um tipo iconográfico exclusivo da figuração de Hera.

De qualquer forma, independente do significado específico atribuído a essas estatuetas de terracota, é importante notar que elas compõem um grupo consistente de representações femininas, o que já sugeria, mesmo antes do achado das inscrições dedicatórias no depósito votivo, que a divindade ali cultuada fosse feminina. Elas, associadas ao restante de grupo de oferendas, contribuem para uma interpretação sobre o regime de oferendas no Heraion de Delos, cujo foco parece ter sido em torno do universo feminino e, aparentemente, com algum interesse mais desenvolvido em torno do casamento.

Como síntese, pode-se dizer que, na maior parte, além de poucos objetos mais específicos e com inscrições portando o nome da deusa, o conjunto é genérico e poderia ser encontrado em santuários variados. Ou seja, não é possível encontrar nesse conjunto a expressão de escolhas específicas de objetos relacionados exclusivamente a Hera. Ao contrário, o culto dela em Delos foi caracterizado pela presença de oferendas específicas ocasionalmente, mas, de maneira ampla, objetos de uso genérico caracterizam de forma mais adequada o conjunto de oferendas. Além disso, há poucas referências a elementos presentes no Heraion indicados em inscrições do período helenístico, tais como uma mesa lustral.

Tendo em mente todos esses vestígios, é possível observar de forma diluída alguns aspectos observados na deusa, tais como a fertilidade provavelmente associada ao casamento, a sua associação com Zeus em termos de um hieros gamos; mas não é possível identificar elementos mais precisos da dinâmica do culto e nem mesmo alguma forma de liturgia própria desse culto. Qual era a dinâmica dos sacrifícios e da deposição das oferendas? Qual a interferência de sacerdotes ou sacerdotisas? Havia uma organização ou ordenação das práticas no contexto do culto? 
De fato, é possível observar, sobretudo para a primeira fase do culto de Hera em Delos, características gerais do regime de oferendas, tais como alguns elementos associados à deusa, a proveniência das oferendas, mas não muito claramente a dos fiéis.

Mare Nostrum (Laky e Angliker): No Museu de Delos, há esculturas curiosas como duas pombas que fizeram parte do programa escultural do templo. Você poderia comentar um pouco sobre o programa escultórico?

Francisco: A compreensão do programa escultórico do templo B, o mais recente, é um desafio grande, considerando a quase ausência de elementos figurativos preservados. As esculturas de pombas (A 3122 e A 3123), geralmente atribuídas ao Heraion, não pertenceram realmente a esse santuário. É o que diz Antoine Hermary, na publicação Sculptures archaïques de Délos: deux lions, une sirène et deux oiseaux, depois de estudar a documentação relacionada a essas esculturas, tais como fotografias da época de seu achado e as anotações dos cadernos de campo; que indicou que o local do achado é a região sudeste do lago, próximo da Ágora dos Italianos.

De fato, uma delas (A 3122) foi encontrada nesse contexto, conforme indica a documentação citada; já a outra (A 3123), permanece com a proveniência incerta (ela já havia sido encontrada antes, mas a informação sobre sua proveniência foi perdida). Talvez, achados externos a Delos, relacionando Hera com a figura de uma pomba, além de ter sido encontrado no depósito votivo do Heraion algumas figuras femininas portando pombas, tenham influenciado a consolidação dessa informação equivocada que ainda é apresentada no Museu de Delos e no GD.

Dessa forma, o único elemento figurativo escultural do Heraion de Delos que conhecemos são as figuras de leões que decoram a sima do templo B (ver fig. 10), cuja datação provável é do primeiro quartel do século V a.C. A figura da cabeça de leão nessa situação não apresenta muita especificidade no que se refere ao programa escultórico do templo B, considerando que essa era uma solução comum na decoração arquitetônica em geral; ou seja, não há uma conexão específica com a deusa Hera. 

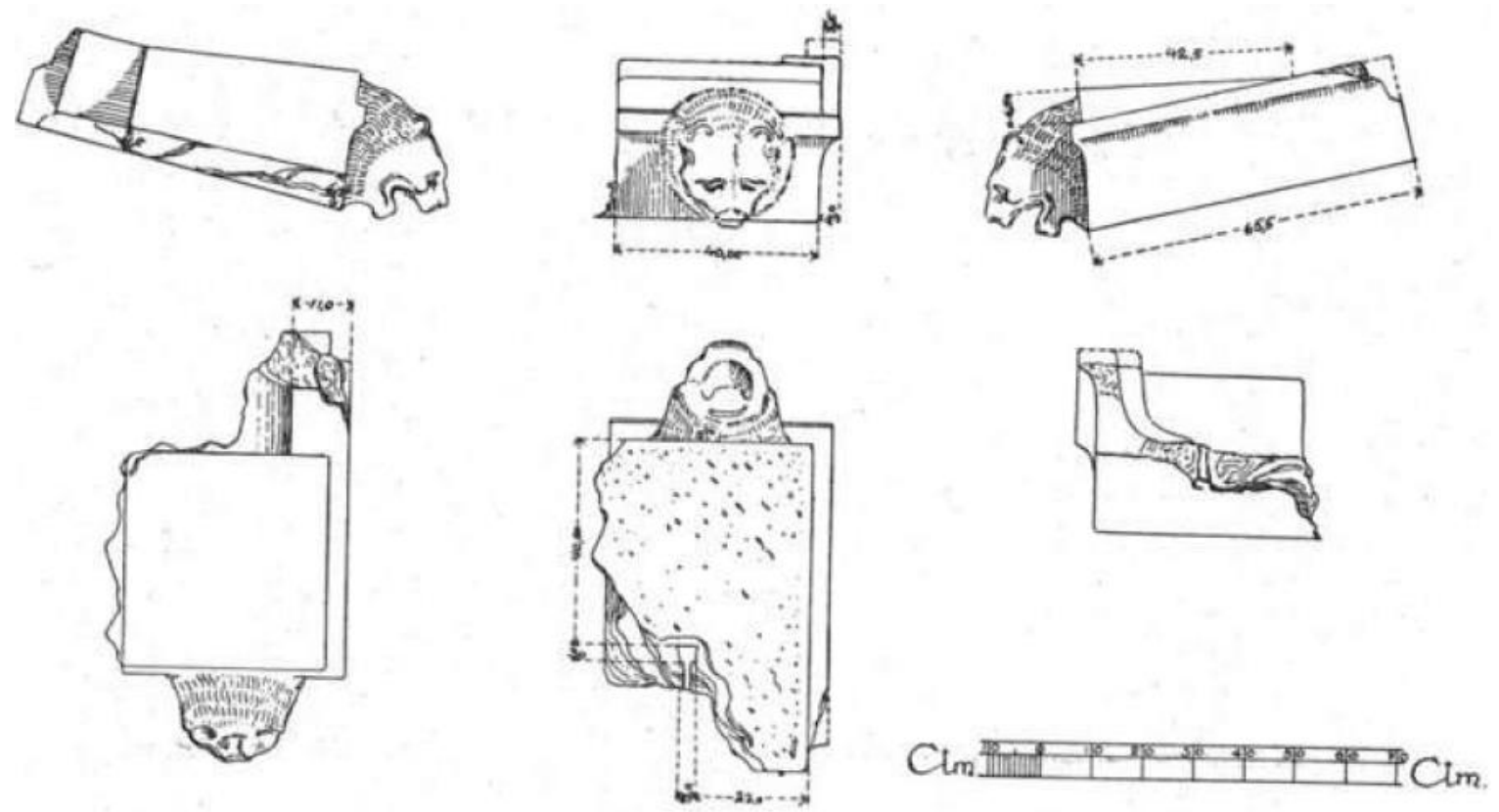

Figura 10: Desenho de cabeça de leão compondo parte da sima do templo B (extraído de Plassart, EAD 11).

Mare Nostrum (Laky e Angliker): Você poderia comentar algo sobre a distância entre o Heraion e o Santuário de Apolo e a proximidade do Heraion e o Kynthion no monte Cinto?

Francisco: Como dito, atualmente, pensamos que o culto de Hera em Delos teve início no século VIII a.C. e que, no século VII a.C., ele foi intensificado. Essa é uma interpretação mais diretamente ligada à quantificação dos objetos do depósito votivo, que ainda merece ser mais aprofundada a partir de leituras sociológicas. Por exemplo, a compreensão de formas específicas da primeira fase do culto, correspondente ao geométrico recente, de baixa intensidade (do ponto de vista quantitativo), mas já demonstrando certa integração com as formas do culto de Hera em outros Heraia.

Mesmo que sejam poucos objetos do geométrico recente encontrados no depósito votivo (são 16 objetos repertoriados por Dugas), eles podem ser associados a outros vestígios encontrados nas escavações do terraço do Heraion, que confirmam uma ocupação consistente no século VIII a.C. Além disso, a natureza específica de parte desse material indica associações com a dinâmica do culto de Hera em um circuito regional - por exemplo, a presença da romã e possíveis associações com características de fertilidade da deusa.

Além dessas comparações no âmbito específico do santuário da deusa em Delos e dos cultos relacionados a ela entre os séculos VIII e VI a.C. em uma perspectiva mediterrânica, a própria situação do santuário de Hera em Delos, considerando a complexidade religiosa das 
atividades na ilha, informa bastante sobre a situação específica do culto de Hera em Delos e sua importância para a compreensão da implementação das atividades religiosas na ilha.

Nesse sentido, é preciso notar que Delos é uma ilha consagrada a Apolo. Ali, tendo em mente as informações paisagísticas e topográficas, epigráficas e literárias, é possível dizer que foi constituído um complexo de cultos, cuja personagem principal era o deus Apolo. Assim, as narrativas literárias, de caráter mitológico, indicam certa oposição entre a tríade apolínea (Apolo, sua irmã Ártemis e sua mãe Leto), de um lado, e Hera de outro.

Na seção deliana do Hino Homérico a Apolo (HHA), Hera atua contra o nascimento dos gêmeos Apolo e Ártemis em dois níveis: a sua fama teria influenciado várias cidades a rejeitarem a chegada de Leto para o parto, exceto Delos; e, ainda, ela retinha consigo a sua filha, Ilítia, divindade essencial para o desenvolvimento do parto. Assim, pensa-se Hera como inimiga da tríade apolínea, dada a narrativa que os coloca em contraposição.

Dessa forma, cabe perguntar, porque ela foi cultuada desde tão cedo em Delos, uma ilha consagrada ao deus Apolo? É preciso notar, a partir de tal questão, que o culto mais antigo registrado em Delos é aquele relacionado a Hera, já que os registros explícitos relacionados ao culto de Apolo datam do século VII a.C., tal como os de Ártemis e Leto; portanto, posteriores. É claro que, sobre essas informações cronológicas, é preciso ponderar um pouco.

Nesse caso, os registros conhecidos pelos arqueólogos indicam mais a nossa limitação do conhecimento do que elementos objetivos da própria ação humana no passado. Por exemplo, na região ocupada pelos santuários de Apolo e Ártemis em Delos, há vestígios que remontam a épocas mais antigas, representadas por material cerâmico do período micênico e protogeométrico; portanto, anteriores àquele material do geométrico recente encontrado no Heraion.

Entretanto, esse material antigo relacionado à região dos santuários de Apolo e Ártemis não são claramente conectados ao culto desses deuses. Diferente dos modelos de romã, que indicam um elemento específico do culto de Hera, como visto, o material mais antigo encontrado na região dos santuários da tríade apolínea não pode ser conectado diretamente à atividade cultual. Dessa forma, o cenário é o seguinte: a partir dos registros arqueológicos, o culto mais antigo é aquele relacionado a Hera; depois dele, há, seguramente, elementos que indicam o culto de Apolo com alguma intensidade já no início do século VII a.C. Além disso, no mesmo século VI a.C., a narrativa sobre o nascimento de Apolo e Ártemis teria sido registrada (não se sabe se a partir de narrativas anteriores oralmente transmitidas ou respondendo diretamente ao contexto de consolidação do culto de Apolo em Delos), na seção 
deliana do HHA, que, apesar do grande debate sobre sua datação, é geralmente situada em algum ponto do século VI a.C.

Entretanto, pode ter havido atividade cultual relacionada a Apolo e à tríade apolínea antes disso. Sabemos que, em vários contextos, atividades cultuais não deixam claros registros. Por exemplo, a construção de templos, em vários santuários, não foi desenvolvida. E mesmo o elemento básico dos cultos, o altar, poderia ser composto por amontoado das cinzas de oferendas anteriores ou por materiais que não permaneceram. O que quero dizer é que há a possibilidade de ter havido atividade cultual relacionada à tríade apolínea antes ou ao mesmo tempo da fase inicial do culto de Hera em Delos; mas, sobre isso, não podemos dizer nada com muita certeza.

Mesmo na publicação mais recente da série EAD sobre o santuário de Apolo em Delos dirigida por Roland Étienne (Le sanctuaire d'Apollon à Délos, EAD 44) o capítulo que discute a cronologia inicial desse santuário (Origines du sanctuaires d'Apollon) escrito por Francis Prost indica que, sobre esse tema, não há nenhuma novidade. Ou seja, apesar de ser bastante razoável pensar que o culto de Apolo já tivesse sido instaurado antes do século VII a.C., não há nenhum vestígio que confirme essa hipótese, que permanece ainda apenas como sugestão. Como síntese, é complicado estabelecer a situação topográfica do Heraion de Delos baseandose exclusivamente na oposição entre Hera e a tríade apolínea, considerando que não temos certeza que o culto a Apolo e Ártemis, os mais antigos da tríade, já tivessem sido estabelecido na época do início do culto de Hera no sopé do Cinto; e, além disso, a própria narrativa que os opõe não pode ser seguramente recuada para aquele contexto. Assim, outras perspectivas de compreensão da situação topográfica do santuário de Hera podem ser propostas - por exemplo, a relação do Heraion com o monte Cinto e, nesse sentido, com Zeus (ver fig. 11).

Como visto, no terraço no sopé do monte Cinto, foi construído uma pequena capela no século VIII a.C. (o templo A), que foi destruída para a construção de um novo templo mais amplo no início do século V a.C. (o templo B), é claramente conectado às atividades do monte Cinto. O templo A, o mais antigo, já era voltado para o monte Cinto, e essa orientação foi mantida na construção do templo mais recente, o templo B.

Sobre a construção do templo A e sua conexão com o monte Cinto, não é possível pensar em uma ligação com o culto de Zeus já no século VIII a.C. (se o culto a Zeus já existia ali nessa época, não deixou vestígios claros); entretanto, entre os séculos VII e VI a.C., havia atividade cultual relacionada a Zeus segundo os vestígios conhecidos: correspondentes ao período arcaico, foram encontradas 12 inscrições em fragmentos de cerâmica no local, duas delas 
indicando explicitamente dedicatórias a Zeus.Desde então, é possível observar, claramente, uma associação espacial entre o culto de Zeus, no topo do monte Cinto, e Hera, na sua base. No momento da construção do templo $\mathrm{B}$, houve uma ampliação do terraço do santuário de Hera, que confirmava essa conexão, na medida em que foi estruturado um temenos que, na sua entrada, dava acesso, ao mesmo tempo, ao santuário de Hera e à escadaria que dava acesso ao santuário de Zeus no topo do Cinto.

Essa conexão entre Zeus e Hera era bastante difundida no mundo grego. Além da constituição das narrativas que associavam os dois como um casal real e divino (o hieros gamos), havia formas de cultos que os associavam diretamente, como aqueles que eram desenvolvidos no interior das gamelia, uma festividade relacionada ao casamento, que tinha como divindades principais Hera e Zeus : por exemplo, na região da Ática, Hera chegou a ser caracterizada como Hera Gamelia e Zeus como Zeus Heraios (Zeus de Hera). Além disso, a associação entre Zeus e Hera na concepção de estátuas de culto também era algo observável em alguns contextos.

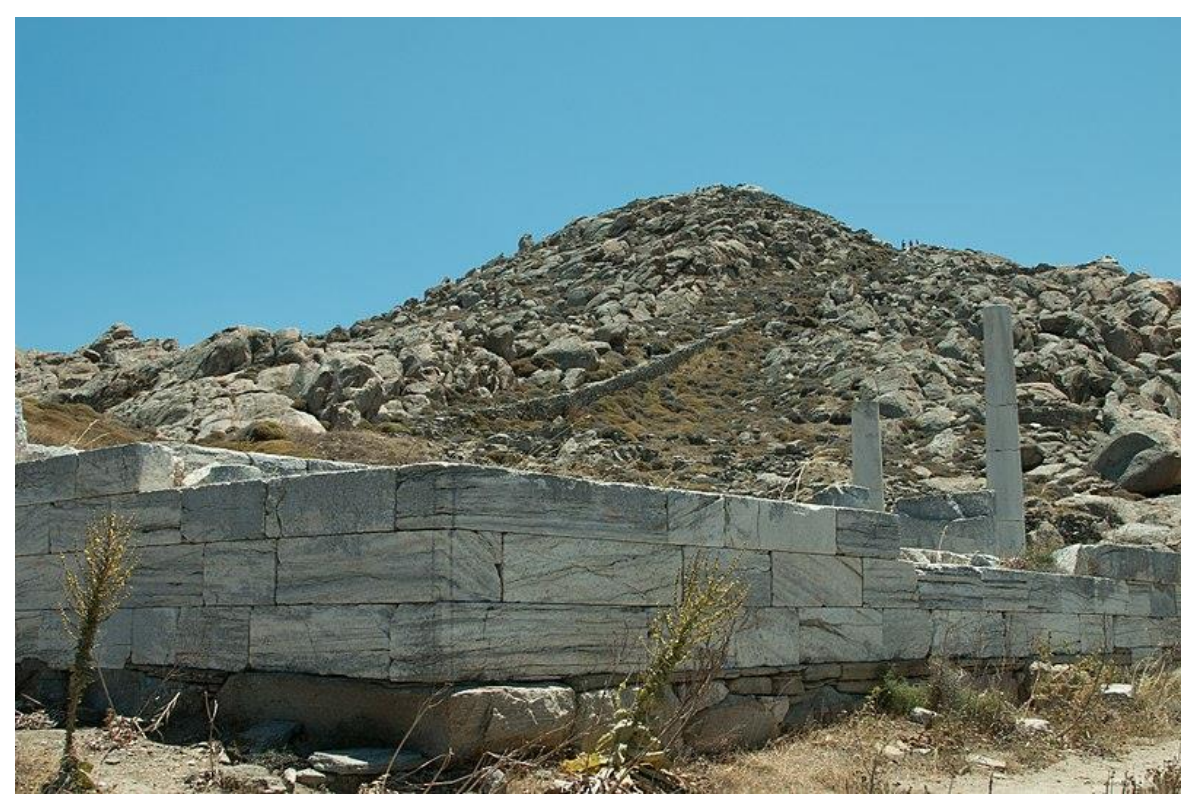

Figura 11: Foto indicando a relação entre o Heraion (quina NO do templo B) e o monte Cinto (arquivo pessoal).

Esta associação com Zeus já no período arcaico, no plano da configuração espacial desses santuários, é mais importante do que parece. Hera, como esposa de Zeus, a esposa-irmã, filha de Cronos e Reia como Zeus, é uma caracterização da deusa que começa a ser consolidada no plano poético. Por exemplo, é assim que ela aparece na poesia homérica e hesiódica; mas, no plano do culto, em alguns contextos, havia importantes narrativas alternativas e tardias, nas quais, Hera poderia ser esposa do Rio Imbrasos ou do Rio Ínaco; ou seja, ela também poderia 
compor um casal sem a presença de Zeus. Foi, aparentemente, no plano poético que ela foi consolidada como a esposa de Zeus incialmente, o que já aparece na configuração inicial do espaço do culto de Hera em Delos - a associação da deusa a Zeus, o que foi manifestado, já no período arcaico, na configuração espacial de seus santuários e na associação de ambos no Dodekatheon de Delos juntos com Atena.

Ainda no século VI a.C., é possível pensar em alguma relação com a deusa Atena. É sabido que, no período helenístico, Zeus e Atena eram cultuados no mesmo santuário no topo do Cinto, além de outros espaços da ilha. Mas, a presença de Atena já cultuada no Cinto no período arcaico é discutível. Se o culto de Zeus é claramente observável desde o período arcaico, sobre o culto de Atena há uma indicação: em Paros, no santuário chamado Delion, foi encontrada uma inscrição, datada do século VI a.C., dedicada à "Atena Cíntia”; ou seja, a Atena do Cinto, sugerindo que a deusa já era cultuada no monte Cinto em Delos, portanto, junto de Zeus já no século VI a.C.

No que se refere à organização dos cultos em Delos no período arcaico, Hera pode ser colocada em relação à tríade apolínea e às questões próprias do mito que narrava a importância de Hera no contexto do nascimento de Apolo e Ártemis. Nesse sentido, inclusive sua distância dos santuários da tríade apolínea (enquanto Hera está próxima do Cinto, os santuários de Apolo, Ártemis e Leto estão mais próximos do litoral da ilha) foi interpretada como uma resposta topográfica à inimizade sugerida na narrativa mitológica. Ainda, ela pode ser pensada nas suas conexões espaciais com o santuário de Zeus e, possivelmente, de Atena, integrando-a a uma dinâmica de culto triplo, como observado no Dodekatheon de Delos, no qual havia um altar para esses três deuses; e, fora de Delos, como a associação de Minerva, Juno e Júpiter, caracterizados como tríade capitolina em Roma já no século VI a.C.

Entretanto, nesse caso, parece mais prudente aprofundar a compreensão das conexões espaciais e suas implicações no plano do culto dessas divindades. Se é possível observar uma clara associação entre Hera, Zeus e Atena no Dodekatheon de Delos desde o período arcaico e em outros contextos externos, a influência disso não deve ser diretamente projetada para a compreensão das associações desses cultos na região do monte Cinto. Tendo a tríade apolínea como referência, além das associações explícitas no plano da narrativa mítica (Apolo, Ártemis e Leto são conectados por laços familiares desenvolvidos no HHA por exemplo), e no plano espacial dos santuários dos três deuses (os santuários de Apolo, de Ártemis e de Leto, apesar de não serem necessariamente contíguos espacialmente, são claramente conectados por uma lógica de orientação dos templos) e de a tríade apolínea também se manifestar no Dodekatheon 
de Delos, havia efetivamente práticas cultuais que associavam essas três divindades, conforme indicam várias inscrições dedicatórias.

Diferente disso, apesar da associação espacial entre os santuários de Hera, Zeus e, possivelmente, Atena, desde o período arcaico, não há indícios de culto conjunto dessas três divindades. Neste caso, em vez de uma tríade, parece que Hera foi associada especialmente a Zeus, deus que também era constantemente aproximado à deusa Atena. Assim, Zeus aparece como um intermediário que, na sua associação com Hera proporcionava o desenvolvimento de formas de culto relacionadas ao casamento (um casal modelar, o hieros gamos); e, na sua associação com Atena, a organização de um culto duplo estabelecido no topo de uma montanha, situação identificável em outros contextos no que se refere à instalação dos santuários de Zeus e Atena.

\section{Mare Nostrum (Laky e Angliker): O Heraion de Delos tinha uma vocação de culto}

\section{local ou pan-helênico?}

Francisco: O culto estabelecido no Heraion de Delos parece ter tido uma vocação sobretudo local ao longo do tempo. Essa é uma questão que merece maior aprofundamento, mas, os dados e interpretações atuais denunciam a lógica de um culto prioritariamente organizado em torno de uma comunidade deliana. Nesse sentido, há duas situações que indicam para isso: o debate sobre a proveniência de boa parte do material do depósito votivo, dessa forma, um material correspondente à primeira fase de ocupação do santuário; e a situação do Heraion de Delos no período helenístico, época de amplo desenvolvimento de práticas sincréticas em Delos.

Sobre o primeiro momento, como visto, o numeroso conjunto de objetos do depósito votivo, correspondente a práticas cultuais em um amplo recorte temporal, apresenta, para boa parte desse período, objetos representativos de diferentes lugares do mundo grego. O material cerâmico, principalmente, tem origem variada; e, sobre o conjunto de terracotas, é possível observar certa consistência de origem jônica. Essa situação foi interpretada por alguns autores como presença jônica na ilha manifestada materialmente nos cultos.

Ora, sobre a presença de jônios em Delos não há dúvida (é só lembrar a influência de Polícrates de Samos na ilha no século VI a.C.); entretanto, não é possível dizer se essa presença interferiu efetivamente na organização e desenvolvimento de certos cultos, como aquele que se manifestou no Heraion. A massiva presença de terracotas de origem jônica, bem como de vasos de cerâmica daquele local, basearam interpretações sobre um culto realizado por um 
comunidade jônica e, mais que isso, que a função do Heraion de Delos fosse uma espécie de substituto no contexto cicládico do grande Heraion de Samos para suprir as demandas religiosas dos jônios presentes em Delos principalmente.

Essa interpretação é bastante problemática, na medida que conecta diretamente um elemento historicamente conhecido (a presença de representantes da comunidade jônica em Delos) ao material arqueológico ali encontrado. Assim, se havia jônios na região, a consistência da presença de estatuetas de terracotas e vasos de cerâmica estariam diretamente conectados a eles. Entretanto, é preciso notar que os processos que permitiram essas duas situações (jônios em Delos e objetos de origem jônica ali encontrados) poderiam ser diversos, já que, no caso da presença desses objetos relacionados ao culto, poderia haver certo encaminhamento para ilha através de um mercado de distribuição da cerâmica e terracotas criados em polos produtivos da região da Jônia e não necessariamente trazidos pelos jônios.

A interpretação sobre uma consistente presença jônica, que foi associada à própria reorganização do santuário de Hera na sua segunda fase por alguns autores, conecta a influência de Polícrates de Samos em Delos na segunda metade do século VI a.C., estabelecendo um novo domínio sobre a ilha que era, até então, situada sob a tirania de Lygdamis de Naxos (apoiado por Pisístrato), o que teria proporcionado uma afluência de fieis jônios na ilha e, mais que isso, a renovação do Heraion já que a atividade cultual teria sido efetivamente ampliada ali. As terracotas de origem jônica seriam as representantes mais significativas da presença jônica no culto de Hera.

Entretanto, há alguns pontos que podem ser reavaliados. Em primeiro lugar, a coerência temporal entre a presença de Polícrates em Delos e a época de renovação do Heraion não é mais sustentada dada a interpretação de parte significativa do material do depósito votivo: um consistente conjunto de vasos de cerâmica ática, cuja cronologia avança até o primeiro quartel do século V a.C.

Esse novo referencial temporal para o fim da primeira fase de ocupação e o início da nova fase, relacionada à renovação do santuário, parece não ser coerente do ponto de vista temporal com o poderio samiano sobre Delos, na medida que a influência de Polícrates se manifestou na ilha entre c. 525 a.C., época que a dominação ateniense (direta ou indireta) sobre a ilha se esfacela, até a morte do tirano em 522 a.C. Ainda, é preciso considerar o desenvolvimento da guerra contra os persas e a instituição, na ilha, da sede da liga liderada pelos atenienses. Além disso, a atuação de Polícrates em Delos parece que estava mais ligada ao santuário de Apolo do que ao Heraion. 
Sobre a forte presença de terracotas jônicas no depósito votivo, ela dividia espaço com uma consistente presença de vasos de cerâmica de origem ática, o que desabona uma coerência direta entre a origem das oferendas e dos fieis. É preciso lembrar, ainda, que a forte presença de vasos de cerâmica coríntia, como visto, não podem ser interpretados diretamente como uma forte presença de fieis oriundos da região de Corinto. Considerando isso, a explicação parece ser mais conectada com as redes comerciais que atravessaram objetos produzidos por vários polos produtivos gregos.

Ainda sobre esse tema, é importante dizer que alguns desses objetos de origem variada encontrados no depósito votivo do Heraion portam dedicatórias a Hera, e, a partir da análise estilística da escrita e do dialeto, observa-se que tal escrita era muito possivelmente deliana. $\mathrm{Ou}$ seja, objetos de origem jônica, ática e até coríntia portando inscrições produzidas por delianos. É claro que tais informações não esclarecem completamente a questão, mas parecem fragilizar a interpretação do Heraion como um santuário ligado prioritariamente à comunidade jônica no século VI a.C.

Essas informações indicam algo sobre as características de abrangência do culto em torno de Hera em Delos entre os séculos VIII ao V a.C. Para contextos posteriores, há pouquíssima informação sobre o alcance geográfico do culto (se era estruturado em nível local/deliano, regional/cicládico ou mediterrânico/pan-helênico). Para compreender um pouco melhor essa projeção, é preciso recorrer a um cenário comparativo. E, nesse sentido, indicarei alguns elementos próprios do culto de Zeus em Delos no período helenístico, sua inserção em ambiente de práticas sincréticas e a situação do culto Hera nesse contexto.

De início, é importante notar que, nesse período, o culto de Hera não era integrado ao intenso ambiente sincrético que se estabelecera em Delos. Hera, junto a Anios (o herói fundador), Ilítia e Leto não foram sincretizados; enquanto Zeus foi muito consistentemente associado a divindades "estrangeiras" variadas. Ao lado do Heraion, por exemplo, Zeus é cultuado (como Zeus e Zeus Kynthios) no amplo complexo do Serapeion, onde ele também aparece como Zeus Ktesios e Zeus Ourios; mas, esse fenômeno não aconteceu apenas ali: além do culto sincretizado de Zeus, é possível perceber essa formulação sincrética em torno de Zeus associando-o a outras divindades que, até então, não povoavam os santuários do mundo grego com tanta intensidade.

Essa situação indica alguns possíveis aspectos do culto de Hera nesse período em perspectiva comparativa: Hera é uma das poucas divindades que se manteve exclusivamente grega na paisagem do monte Cinto e imediações, que foi marcada por cultos sincréticos de Zeus 
e outras divindades como Afrodite e Héracles. Dessa forma, Hera não parece ter sido amplamente cultuada entre as comunidades estrangeiras que passavam cada vez mais frequentar a ilha. Além disso, enquanto o culto de Zeus, antes delimitado prioritariamente no topo do monte Cinto, foi espalhado em outros espaços do monte Cinto além do Kynthion, e também nas regiões do sopé do monte; o culto de Hera continuava amplamente delimitado na região do Heraion, excetuando-se sua presença no Dodekatheon (junto de Zeus e Atena) e em uma oferenda no santuário de Apolo, e talvez também no porto da ilha.

\section{Mare Nostrum (Laky e Angliker): Há evidência de uma estátua de culto no Heraion?}

Francisco: Sim. Quando as ruínas do templo B foram encontradas, havia, no interior de sua cella, um solo com mosaico de pequenos seixos rolados e, sobre ele, um conjunto de pedras com recorte retangular, alinhadas e organizadas em "U” (ver fig. 12 e 13). Esse conjunto, por sua posição no templo e por suas características, parece ter sido a base de uma estátua de culto, sobre a qual não há informações específicas; entretanto, um conjunto de informações indiretas pode ajudar a pensar em alguns elementos da estátua de culto ali presente. Mas, de antemão, é importante dizer que características específicas, como a época de sua instauração e elementos estéticos não são conhecidas.

A posição atual dessa base não corresponde à sua composição na antiguidade. Em 1911, no aprofundamento da escavação no interior da cella do templo B proposto por Roussel, a base foi retirada pelos escavadores e reposicionada logo atrás do templos $\mathrm{B}$, onde permanece até os dia atuais, sobre uma pequena plataforma de pedras. Esse não foi o único caso de reposicionamento. Vários dos elementos foram encontrados de forma aleatória nas escavações e, nesse sentido, foram reorganizados no espaço do sítio arqueológico de forma diferente. No caso das duas colunas do templo B, por exemplo, elas foram remontadas de forma equivocada no que seria a sua posição original.

Elementos do altar também foram remontados na posição de sua constituição original; e outros, cuja compreensão da sua posição não era clara, foram colocados exatamente ao lado do altar. Por fim, vários blocos que compunham as paredes e outros segmentos do templo B foram organizados em carreiras ladeando a construção. Ou seja, a situação da base de culto atualmente é produto dessa movimentação empreendida pelos escavadores que, desde o início do século $\mathrm{XX}$, empreenderam escavações arqueológicas em zonas do terraço e no interior do templo B. 


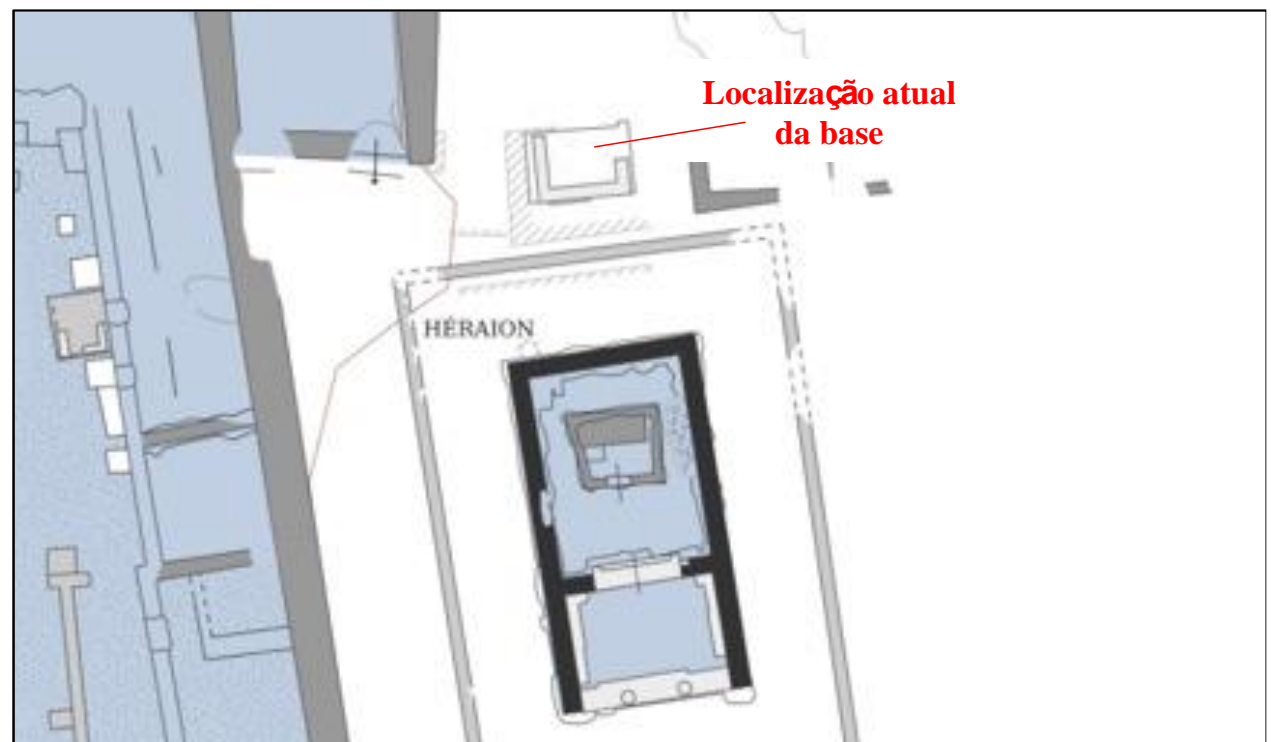

Figura 12: Situação da base da estátua no terraço e sua relação com outros monumentos (extraído do WebSig Delos e adaptado).

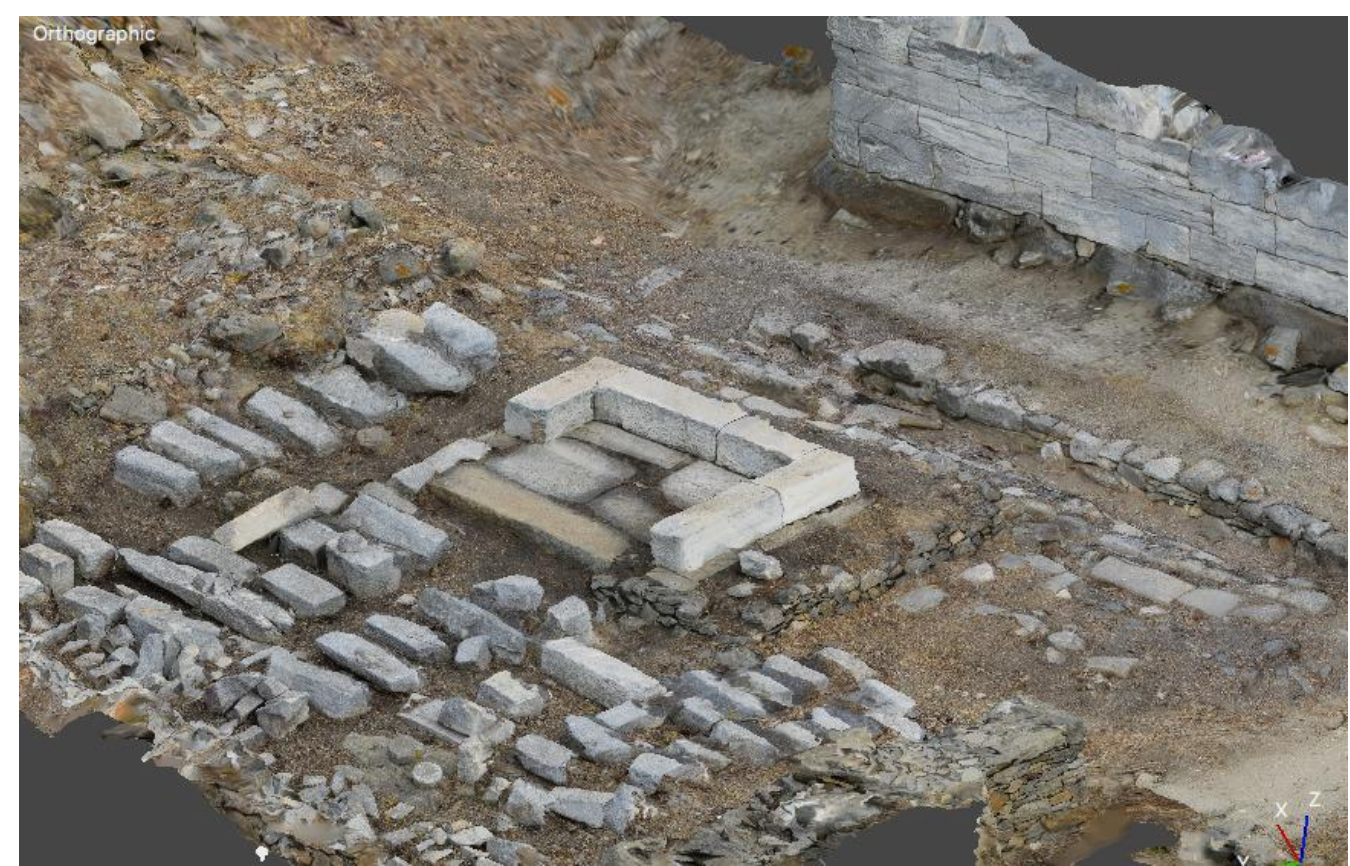

Figura 13: Imagem a partir de modelo 3D dos blocos da estátua remontados (autora: Carolina Machado Guedes a partir do programa Metashape Agisoft).

Sobre as características mais específicas da estátua de culto na sua formulação original, há três elementos importantes que podem auxiliar na compreensão de sua estrutura original: a própria base, uma estrutura de terracota do depósito votivo e algumas inscrições do período helenístico que indicam algo de sua materialidade.

No conjunto de oferendas, há uma parte significativa de figuras femininas sentadas que forma interpretadas por Lévêque, no artigo Héra et le lion, d'après les statuettes de Délos $(\mathrm{BCH}$ $73,1949)$ como representações da própria deusa; o que foi replicado por Plassart (EAD 11) e 
também por Laumonier (EAD 23), como visto, com reservas. Na interpretação de Laumonier, que busca uma terminologia mais neutra, a figura entronada é caracterizada como uma forma de representação de deusas ou sacerdotisas na coroplastia da região da Jônia. Entretanto, mesmo considerando o ambiente claramente duvidoso de interpretação, a presença do trono parece bastante significativo.

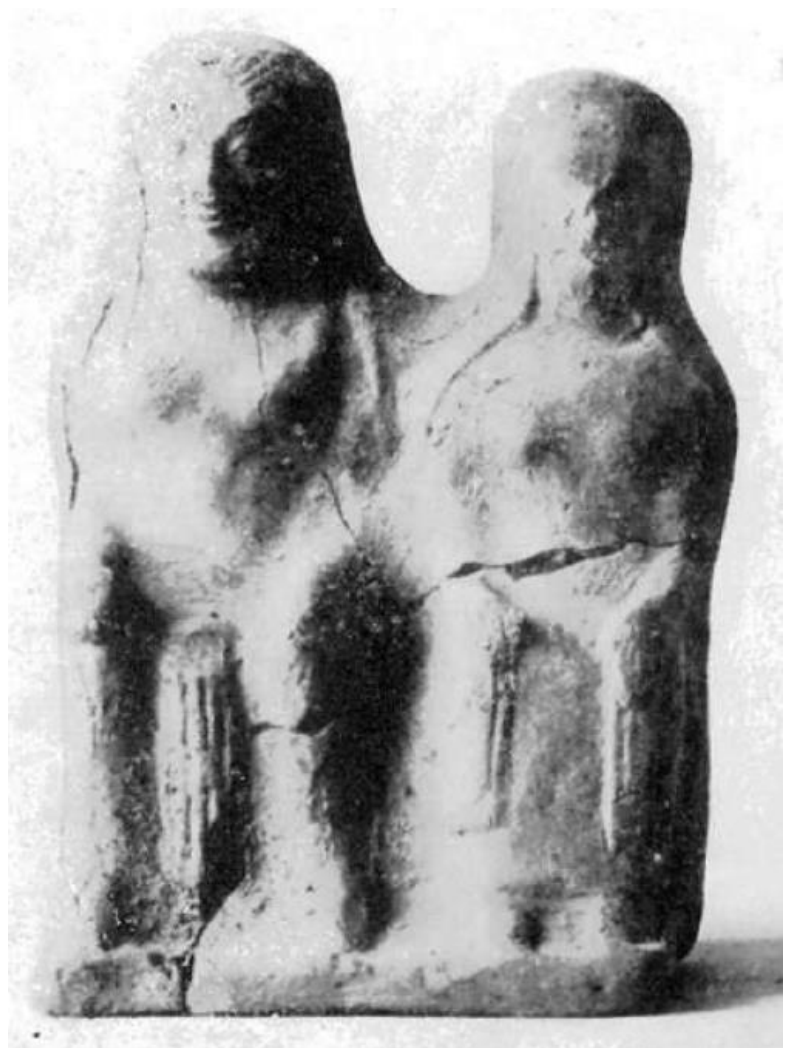

Figura 14: Estatueta de terracota de origem jônica (alt. $15 \mathrm{~cm}$ ) proveniente do depósito votivo do Heraion (extraído de Plassart, EAD 11).

Esse modelo caracterizado por uma figura feminina entronada também é encontrado em algumas esculturas de mármore encontradas, seja no terraço do Heraion, seja nas suas imediações. E, novamente, a presença do trono é um elemento marcante. Nesse contexto, uma estatueta é bastante significativa para esse debate: trata-se de uma escultura em terracota de pequenas dimensões (um achado do depósito votivo), representando um casal - uma figura feminina e uma masculina (ver fig. 14) - interpretada como um casal não identificado (talvez os ofertantes ou o hieros gamos Zeus e Hera). Se aceitarmos que se trata de Zeus e Hera, essa seria uma indicação indireta de uma das formas de representação coerente com a estrutura larga da base da estátua formada pelos blocos acima citados. Mas, é importante dizer, a indicação é bastante indireta. 
Além disso, há um conjunto de inscrições do período helenístico com elementos relacionados ao inventário dos objetos do Heraion e, um deles, é a presença de duas estátuas acrolíticas, o que reforçaria a presença dessa estátua dupla. A informação epigráfica não é clara nem detalhada. Sabemos que as estátuas possuem vestes de linho, que são acrolíticas e que dividem o espaço com outras estátuas (muito possivelmente menores) e outros objetos. Dessa forma, as dimensões da base, a terracota apresentando o casal entronado, a indicação das duas estátuas no interior da cella, são indícios importantes e que permitem pensar de maneira geral na forma da estátua de culto.

A presença de uma estátua associando Hera a Zeus não seria novidade no mundo grego e, em Delos, reforçaria a própria conexão espacial entre os santuários desses deuses que, como visto, foram aproximados em alguns contextos; e, em Delos, certamente foram associados espacialmente. Seria, assim, a estátua de culto conectada a essa associação entre Zeus e Hera: uma estátua dupla apresentando o hieros gamos?

\section{Mare Nostrum (Laky e Angliker): É possível comentar algo sobre as fontes} epigráficas e como elas podem auxiliar a compreensão das atividades no Heraion de Delos?

Francisco: As inscrições diretamente associadas ao Heraion de Delos são poucas, mas bastante significativas. Elas são correspondentes, basicamente, à primeira e última fase de ocupação do santuário; portanto, correspondentes ao que caracterizamos como Heraion I e III. O conjunto mais antigo é composto principalmente por inscrições dedicatórias em vasos e uma sobre uma máscara de terracota do depósito votivo, correspondentes à primeira fase do culto; e algumas inscrições relacionadas à administração do santuário no período helenístico.

Sobre o primeiro grupo de inscrições, que já foi comentado acima, basta lembrar que ele é composto por dedicatórias presentes em um fragmento de máscara de terracota de origem jônica, em um vaso de origem coríntia e, na maior parte, em vasos áticos. E, a partir da análise estilística e, em alguns casos, dialetal, deduz-se que são inscrições produzidas por delianos. Mais que isso, há quem arrisque dizer que sejam oferendas apresentadas prioritariamente por mulheres, já que a maior parte dos nomes preservados de fieis é feminina.

Sobre as inscrições do período helenístico, elas foram publicadas na série Inscriptiones Graecae (IG) e Inscriptions de Délos (ID). Sua reunião em uma perspectiva interpretativa foi feita por Philippe Bruneau na obra Recherches sur les cultes de Délos à l'époque hellénistique et à l'époque impériale (1970), que as dividiu em quatro categorias: (1) as contas dos hieropes 
(oficiais responsáveis pelo culto) - o maior grupo de inscrições -; (2) os inventários atenienses do Heraion; e (3) o grupo menos expressivo, oferendas e dedicatórias; por fim, ainda, ela indica uma outra categoria específica (4) - a inscrição no altar do Dodekatheon. Esse conjunto de inscrições bastante fragmentadas foi datado entre os séculos III e I a.C.

A primeira categoria, relacionada aos hieropes, é composta por 21 inscrições que tratam da administração do santuário. Nele, é possível encontrar informações sobre o estado de preservação do templo e algumas iniciativas para executar reparos e aquisições. É perceptível, por exemplo, que havia a necessidade de empenhar despesas para aquisição de telhas e algum mobiliário para o santuário, além da obtenção de véus para a deusa (presume-se, para a estátua da deusa).

A segunda categoria organiza um grupo composto por 6 inscrições que indicam os objetos presentes no interior do templo. A indicação de duas estátuas acrolíticas com mantos de linho (presume-se que fossem as estátuas de culto), além de mais duas outras estátuas, duas mesas de mármore, um thymiaterion de bronze, plaquetas votivas (uma delas faz menção à Hera no porto), entre outros. Além dessas informações específicas sobre o Heraion, duas inscrições colocam Hera em outros contextos delianos, como um kymbion dedicado a Hera encontrado no santuário de Apolo e a aproximação da deusa a Zeus e Atena em um dos altares do Dodekatheon como já foi dito. Hera, ainda, aparece em uma inscrição com dedicatória a ela e a Atena pelo trierarca Medeios.

Esse grupo de inscrições indica principalmente elementos específicos do santuário da deusa, permitindo o aprofundamento da compreensão sobre os aspectos da estátua de culto e da dinâmica da ocupação do santuário, que, nos séculos III e II a.C., ainda merecia atenção na medida que a deusa ainda era cultuada e, mais que isso, o templo era alvo de reparos. Além disso, a tímida presença da deusa em outros contextos (no Dodekatheon, no santuário de Apolo, talvez no porto e ao lado de Atena) também é indicada.

\section{Mare Nostrum (Laky e Angliker): Qual o histórico de escavações francesas em Delos}

\section{e especialmente das escavações brasileiras?}

Francisco: As pesquisas sobre o Heraion de Delos passam, quase invariavelmente, pela École française d'Athènes, uma instituição francesa que se estabeleceu na Grécia em plena atuação imperialista de algumas nações europeias. Assim, é importante notar que tal empreitada não visava exclusivamente a criação de impérios coloniais baseados na exploração econômica de outros povos, mas também a interposição dessas nações como produtoras de conhecimento. 
Nesse caso, a Grécia tinha um papel fundamental na construção de um discurso sobre a origem da civilização ocidental que teria dado base à estrutura cultural e política dos impérios europeus do século XIX.

A EfA foi a primeira instituição estrangeira que se instalou, em 1846, no território grego, seguida pela criação de várias outras instituições depois disso, o que organizou, em grande medida, a produção de conhecimento, sobretudo arqueológico, sobre a Grécia antiga. Ou seja, a história das intervenções arqueológicas em Delos, e especialmente no Heraion local, está ligada intimamente à história dessa instituição e de seus pesquisadores, na medida em que, sobre Delos, constituiu-se um farto conhecimento sobre o passado com a mediação dessa instituição e prioritariamente em língua francesa. Havia, também, a participação de pesquisadores gregos, que representavam um país recém independente, e o acolhimento de pesquisadores estrangeiros no quadro de membros da EfA.

Além da pesquisa desenvolvida por pesquisadores gregos, com menor intensidade, e amplamente pelos pesquisadores francesas no âmbito da EfA, essa instituição abrigou pesquisadores de outras nacionalidades, geralmente francófonos, tais como suíços, belgas e canadenses, mas também gregos e brasileiros. Neste caso, considerando as pesquisas desenvolvidas em Delos, Ulpiano Toledo Bezerra de Meneses, Haiganuch Sarian e Gilberto da Silva Francisco, que foram membros da EfA, desenvolveram, e ainda desenvolvem, pesquisas relacionadas a projetos dessa instituição. Foi, dessa forma, que foi organizado o conhecimento arqueológico sobre Delos, incluindo o Heraion, o que apresentarei em linhas gerais na sequência.

Em 1864, a então recém criada École française d'Athènes (1846) enviara pesquisadores para a ilha de Delos para o reconhecimento do local, o que permitiu a criação de um programa de escavações que foi iniciado em 1873, objetivando, principalmente, o reconhecimento de estruturas arquitetônicas e inscrições abundantes na ilha. As primeiras impressões sobre o Heraion de Delos como um dos objetos de estudo da EfA aparecem nesse contexto; entretanto, já havia registros de viajantes desde o século XVIII sobre elementos desse santuário; sobretudo relacionados ao templo $\mathrm{B}$. Ou seja, o processo de produção de conhecimento desde o século XVIII até o início do século XX é o que poderíamos chamar de primeira fase das pesquisas 
sobre o Heraion. Um período no qual, cabe notar, o conhecimento sobre esse santuário era ainda bastante desorganizado.

Como visto, algumas intervenções na região do Heraion foram empreendidas já no século XIX, mas a identificação da divindade cultuada naquele espaço ainda não havia sido feita. Só em 1909, as primeiras escavações sistemáticas do terraço foram iniciadas sob a liderança de Pierre Roussel, que, naquele ano, escavou trechos do terraço. Como síntese, além de achados significativos como cerca de 20 estatuetas de terracota e de elementos arquitetônicos, Roussel percebia a necessidade de entender melhor as estruturas do templo B e, mais que isso, se uma escavação mais detalhada daquele monumento não ofereceria mais dados sobre a divindade ali cultuada. Foi, nesse sentido, que ele empreendeu, em 1911, a escavação da cella do templo B e encontrou o depósito votivo e as ruínas do templo A.

A escavação de 1911 marca uma nova fase dos estudos do Heraion de Delos. Em primeiro lugar, porque o santuário passou a ser identificado com mais clareza pelos pesquisadores. Depois, porque estruturas de uma fase anterior do culto foram reveladas, com itens importantes como o próprio edifício conectado ao culto de Hera em uma época mais antiga, e o conjunto de oferendas representativo de um período de mais de 200 anos, o que permitiria pensar com mais profundidade em questões como a intensidade e variedade da dinâmica do culto ali estabelecido.

O achado do depósito votivo do Heraion de Delos é um marco importante não apenas para a compreensão da história do culto de Hera em Delos, mas para a própria história do culto em contexto cicládico. Na época, o achado foi destacado em publicações da imprensa europeia, e foi imediatamente alvo de interesse de alguns pesquisadores. Por exemplo, Charles Dugas, que publicou o conjunto de vasos de cerâmica do depósito votivo em 1928 no volume 10 da série EAD, em 1912, já havia publicado uma espécie de esboço da tipologia desses vasos de cerâmica (Un trésor céramique à Délos, no periódico "La révue de l'art ancien et moderne"). Foi, também, em 1912, quando o material encontrado em 1911 começou efetivamente a ser estudado, que foram identificadas as várias inscrições dedicadas a Hera e foi quando se consolidou a identificação do santuário ao culto de Hera; portanto, caracterizando aquele complexo paisagístico religioso como um Heraion.

Como resultado, os achados de 1911 proporcionaram a produção de dois estudos em 1928, os já citados volumes da série EAD 10 e 11 . O primeiro deles, específico sobre o material cerâmico proveniente do depósito votivo do Heraion; o segundo, sobre os vários santuários da região do monte Cinto, com interesse destacado sobre o santuário de Hera. Além disso, no 
Museu de Delos, enquanto o próprio edifício foi se organizando, o destaque desse material do depósito votivo do Heraion era perceptível, na medida em que, nas vitrines da sala devotada à cerâmica, a maior parte dos vasos expostos era proveniente do depósito votivo do Heraion.

É preciso notar, nesse sentido, a importância do Museu de Delos nesse processo. Antes de sua construção, que foi iniciada em 1904, boa parte do material arqueológico encontrado nas escavações tinha destino um pouco incerto. Sabe-se que a maior parte foi sediada no Museu de Míconos e alguns objetos considerados mais interessantes poderiam mesmo ser deslocados para o Museu Nacional Arqueológico de Atenas. Mas, há um conjunto expressivo de objetos cuja localização atual não é conhecida. No tocante ao Heraion de Delos por exemplo, a maior parte dos objetos encontrados nas intervenções de campo até 1909 não são atualmente localizados.

A partir desse material encontrado em 1911, ainda, foi publicado outro volume da série EAD (23) sobre as terracotas. A publicação tem interesse mais amplo, mas a presença do grupo das estatuetas e máscaras de terracotas do depósito votivo (e a inclusão de alguns achados anteriores) é bastante destacado. Ou seja, as escavações de 1911 basearam as três publicações mais importantes sobre o Heraion de Delos até o momento.

Entretanto, ao longo do século XX, algumas questões ainda duvidosas proporcionaram a retomada tímida das escavações no local: Paul Bernard, em 1958, visando a compreensão da cronologia do templo $\mathrm{B}$, trabalhou em uma sondagem na região de sua quina sudoeste, encontrando, além de objetos como um vaso ático de figuras negras atribuído ao então caracterizado como "Pintor do Heraion", algumas estruturas construídas (trecho da quina de um muro); e Jean Ducat, em 1964, escavou o setor oeste partindo do muro do templo B, encontrando outro trecho do muro Y e também de outro muro ao lado (o muro X), além de fragmentos de cerâmica geométrica (ver fig. 3).

Apesar desses achados significativos, essas sondagens foram apenas publicadas de forma muito sintética no BCH em 1959 e 1965 (ver DAUX, 1959 e 1965), sem maiores consequências nas interpretações gerais sobre o Heraion. Desses dados efetivamente novos, as publicações agregaram, de forma tímida, a informação dos fragmentos geométricos encontrados por Ducat e, respectivamente, a possibilidade de se pensar em outro cenário de datação do início do culto; como, por exemplo, no GD, que acaba optando pela tradicional datação do século VII a.C. para esse início.

Essa é o que se pode chamar de segunda fase de estudos arqueológicos sobre o Heraion de Delos, que começa em 1911 (talvez possa ser recuada para 1909) com os grandes achados e seus desdobramentos: publicações cujo objetivo mais direto era a reflexão sobre segmentos 
específicos da documentação e uma visão pouco aprofundada sobre o conjunto e, mais que isso, sobre o fenômeno sociológico.

Outros exemplos dos desdobramentos dessa primeira fase são publicações como Le mobilier délien (EAD 18) por Waldemar Déonna, de 1938, e Les Mosaïques (EAD 29) por Philippe Bruneau, de 1972, nos quais os vidros e corais provenientes do Heraion, no primeiro caso, e o mosaico da cella do templo B, no segundo, são repertoriados em um grupo que abrange também objetos provenientes de várias outras regiões da ilha. É digno de nota, ainda, é o apêndice sobre a fachada principal do templo B na publicação de 1995 por Philippe Fraisse et Christian Llinas, Documents d'architecture hellénique et hellénistique (EAD 36).

Fora do âmbito das publicações da EfA na série EAD, no GD ou no $\mathrm{BCH}$, os debates sobre o Heraion de Delos também foram influenciados pelos achados de do início do século XX e pelas publicações baseadas neles. Por exemplo, existe um grande interesse pelos tipos de cerâmica do depósito votivo. Além disso, algumas publicações mais recentes, como o capítulo Héra, Apollon et l'Héraion de Délos à la période archaïque de Vinciane Pirenne-Delforge, no livro "Les sanctuaires archaïques des Cyclades" (2017) organizado por Alexandre Mazarakis Ainian, esbarrou na dificuldade de uma visão atualizada dos dados. Ou seja, do ponto de vista das publicações, não há muita novidade sobre o Heraion de Delos.

Entretanto, uma nova perspectiva de compreensão desse debate começava a ser desenvolvida em 1990, quando Haiganuch Sarian tornou-se responsável pela retomada do projeto, já pensado como um estudo do conjunto: os dados topográficos e paisagísticos, as ruínas arquitetônicas, o material cerâmico, as terracotas e ainda um conjunto variado de fontes, que passaram a ser observados a partir de uma visão integrada, a partir de duas perspectivas: a revisão dos dados e interpretações das publicações até então disponíveis e a retomada das atividades de campo visando o detalhamento de aspectos formais e cronológicos dos elementos construídos e sua conexão com a paisagem.

Nesse sentido, um exemplo é emblemático: do conjunto de muros, templos e altar, os principais elementos arquitetônicos do santuário, ainda havia dúvida sobre sua cronologia e sobre a relação entre eles. A interpretação de que um dos muros laterais era o muro de períbolo, mesmo que muito próximo do templo em um espaço amplo do novo terraço, ainda era mantida e, vale dizer, ainda manifestada no GD. A situação externa do altar, portanto, ainda era corrente e os muros X e Y não eram compreendidos efetivamente. Assim, era importante retomar as atividades de campo para sustentar algumas novas hipóteses críticas às interpretações até então vigentes. 
Com a retomada das pesquisas, Sarian estabeleceu um programa visando o estudo do material cerâmico já publicado por Dugas, mas também aquele que foi encontrado por Bernard e Ducat, que ainda não havia sido estudado (ver SARIAN, 1997 e 2000). As missões de 1998 e 2000 em Delos foram caracterizadas pelo estudo desse material, o que já apresentava um cenário diferente das interpretações consolidadas. Por exemplo, o material geométrico encontrado na escavação de Ducat indicava que determinadas estruturas associadas a eles, correspondentes à fase inicial do culto, eram muito possivelmente anteriores ao século VII a.C.

Considerando algumas lacunas na compreensão dos monumentos já estudados e a possibilidade de avançar na compreensão de outros até então quase desconhecidos, Sarian liderou uma série de intervenções no campo, algumas escavações arqueológicas visando reconhecer estruturas já estudas e entender regiões pouco escavadas até então. Em 2002, 2006 e 2008, foram escavadas regiões do santuário, incluindo algumas anteriormente escavadas, mas que ainda poderiam revelar novidades.

É importante saber que intervenções no terraço já haviam sido efetuadas e que, em 1909 especialmente, ele foi amplamente escavado. Entretanto, o objetivo prioritário era revelar as ruínas arquitetônicas que foram escavadas, mas aprofundando sua escavação até a base. Em alguns contextos, foi justamente assim que as novidades foram reveladas.

Nesse sentido, algumas informações passavam a ser consolidadas, como a cronologia mais recuada do início do culto, dado o farto material cerâmico do geométrico recente associado ao muro Y. Tal muro já havia sido escavado parcialmente por Bernard e Ducat, mas foi na escavação liderada por Sarian que ele foi integralmente até sua base, junto ao muro X, revelando uma quantidade consistente de material geométrico efetivamente associada à base do muro. Incluindo-se, ainda, um lécito pouco fragmentado entre as pedras do muro Y.

Além disso, outra região do santuário, cujo interesse dos escavadores antigos foi pouco desenvolvido (a extensão da entrada na extremidade sul do terraço), foi escolhida para a escavação de segmentos do muro, revelando uma consistente presença de cerâmica do período helenístico, inclusive associada à base do muro. (onde foi encontrada uma lamparina quase integralmente preservada) Dessa forma, confirmava-se, ali, a ideia de uma extensão do terraço e reorganização da entrada do santuário no período helenístico.

Esses são apenas alguns dos muitos indícios que tais escavações revelaram. Não caberia, aqui, apresentar os resultados de forma pormenorizada, já que muitos dos novos dados estão ainda sendo estudados. Entretanto, sobre essa nova fase, que ainda está em curso, é importante indicar que, sob liderança de Sarian, foi constituída uma prática de pesquisa desenvolvida por 
equipes compostas prioritariamente por pesquisadores brasileiros; sejam colaboradores, sejam estagiários. O que promoveu a presença consistente de pesquisadores brasileiros atuando nesse projeto, desde 2000.

Essa foi uma importante oportunidade de integrar a pesquisa arqueológica no seio da EfA às estratégias de formação de arqueólogos brasileiros que pesquisam temas relacionados à Grécia antiga. Mais que isso, houve uma significativa colaboração de pesquisadores relacionados a universidades brasileiras, muitos deles docentes, que atuaram nesse projeto, seja nas atividades de campo, de análise de material no Museu de Delos, e no aprofundamento das leituras em bibliotecas especializadas.

Atualmente, mantenho uma equipe composta prioritariamente por pesquisadores brasileiros, entre as atividades do grupo de estudo no Brasil e as atividades de campo na Grécia. Considerando a amplitude cronológica e a grande variedade documental, o objetivo é consolidar um grupo composto por pesquisadores que atuem em diferentes domínios visando o aprofundamento das questões colocadas para a compreensão da história do culto de Hera em Delos. Mais que isso, pensamos na formação de alunos de graduação e de pós-graduação, proporcionando sua efetiva integração ao projeto. Por exemplo, alguns deles já desenvolvem pesquisas diretamente conectadas ao estudo específico do Heraion de Delos, mas também a questões relacionadas como representações e cultos de Hera no mundo grego antigo, o que proporciona ao grupo uma visão mais ampla de características das práticas religiosas relacionadas a Hera.

Considerando essa efetiva participação brasileira, mediada pela EfA, nesse projeto, é importante dizer que, se o objetivo principal é a produção de uma publicação específica sobre o Heraion na série EAD, esse não é o nosso único objetivo. Além da formação de pessoal nas dinâmicas de pesquisa arqueológica especificamente, pensamos em desenvolver diferentes linhas do projeto. Por exemplo, a criação de uma exposição virtual, integrando os dados paisagísticos, arquitetônicos, e dos inúmeros tipos de objetos associados a esse santuário, tais como vasos de cerâmica, terracotas, ossos, vidros, corais, metais etc., integrando às informações que estão, atualmente, desarticuladas. Além disso, trabalhamos para a produção de uma publicação sobre o tema em língua portuguesa, além do desenvolvimento de atividades pontuais relacionadas ao potencial pedagógico do projeto e uma exposição destacando a presença de pesquisadores brasileiros nesse projeto. 


\section{Mare Nostrum (Laky e Angliker): Como a insularidade pode impactar o trabalho de} campo do arqueólogo?

Francisco: A insularidade é um elemento essencial para se pensar na pesquisa arqueológica. Há, nela, aspectos variados a serem considerados na compreensão dos processos passados (em que medida a insularidade influenciou as territorialidades, a constituição de paisagens, a circulação, contatos etc.); mas também da própria dinâmica da pesquisa arqueológica que, nesse contexto, encontra certas dificuldades específicas. No caso de Delos, especificamente, a insularidade é fundamental para se pensar nas dinâmicas estabelecidas na antiguidade e na contemporaneidade.

No que se refere às dinâmicas antigas, a relação entre Delos e a ilha ao lado, Reneia, e a integração de Delos no contexto cicládico e do Mediterrâneo oriental são elementos importantes ligados à insularidade, o que é indicado na narrativa mitológica: Delos é situada em um contexto de ilhas circundantes, o que é associado ao próprio nascimento de Apolo que, depois de seu nascimento, proporcionaria a fixação da própria ilha; ou seja, reconhece-se, nas narrativas mitológicas, certas características específicas desse conjunto de ilhas, imputando-as a caracterização de um grupo articulado.

No caso do culto de Hera em Delos, seu santuário foi instaurado relativamente distante do litoral (a região dominada pelos santuários de Apolo e Ártemis); mas, há, como visto, uma inscrição que faz menção a Hera no porto. O significado dessa presença de Hera no porto é pouco conhecido, mas é importante notar que Hera, em outros contextos, era também caracterizada como uma deusa dos marinheiros.

No tocante à ocupação contemporânea da ilha, é preciso notar que Delos não foi urbanizada desde a modernidade, diferente de várias ilhas cicládicas como Paros, Naxos e Míconos. Essa situação proporcionou certas limitações para o desenvolvimento das pesquisas arqueológicas ali desenvolvidas desde o séculos XIX. Nesse sentido, na ilha, foram construídas poucas edificações relacionadas à guarda e exposição de objetos provenientes do sítio arqueológico (o Museu de Delos) e um certo aparato que responde às demandas das pesquisas arqueológicas, como um grupo pequeno de habitações.

Delos foi listada como patrimônio da humanidade pela UNESCO em 1990 e um dos sítios arqueológicos na região das Cíclades mais visitados por turistas. O complexo da ilha, assim, além das habitações ligadas à estadia dos arqueólogos e guardiões que operam na ilha, possui também o museu citado e um quiosque onde foi instalada uma lanchonete; ou seja, uma estrutura mínima que serve às necessidades dos grupos de turistas que são, em grande medida, 
conduzidos pela ilha por guias autorizados. Há, inclusive, a proposta de alguns percursos sugeridos por um programa distribuído aos turistas, com projeções de tempo diferentes (45 minutos a 3 horas de circulação na ilha).

Essa visitação é bastante intensificada durante o verão grego, o que proporciona uma maior oferta de embarcações que partem de Míconos para Delos, principalmente, mas também de outras ilhas próximas, o que praticamente cessa durante o outono e inverno. $\mathrm{O}$ acesso à ilha, atualmente, depende dessa dinâmica específica ligada ao trânsito de embarcações de vocação prioritariamente turística, que também atende o deslocamento dos arqueólogos em certa medida. Ou seja, não há um serviço de deslocamento específico dos pesquisadores de ampla oferta.

Delos é uma ilha que não apresenta equipamentos urbanos como em outras ilhas cicládicas ou outras ilhas bastante conhecidas como Egina e Creta nas quais as atividades arqueológicas também são intensas. Em Delos, não podemos contar com comércio ou espaço onde são prestados serviços de saúde rapidamente. Dependemos de alguma embarcação que nos transporte até Míconos para acessar tais equipamentos. Dessa forma, é bastante importante programar muito bem as atividades ali desenvolvidas, bem como preparar a equipe para imprevistos, tais como um acidente ou dificuldade de saída da ilha. Nesse sentido, é importante que as equipes que ali operam sejam compostas com, pelo menos, um membro com treinamento para primeiros socorros e que a pequena farmácia mantida nas instalações dos arqueólogos esteja sempre bem suprida.

Além disso, é preciso estar atento às informações sobre a meteorologia, já que isso pode interferir sensivelmente no acesso e saída da ilha. Há épocas em que a navegação na ilha é interrompida dadas as condições meteorológicas desfavoráveis, o que pode durar dias, semanas ou mais que isso. Ou seja, chegar ou deixar Delos depende, em grande medida, da circulação promovida por empresas que tratam prioritariamente do deslocamento massivo de turistas por mar e, além disso, das condições meteorológicas.

No contexto específico da pesquisa, é interessante notar a dificuldade de acesso a locais próximos, como o caso da ilha de Reneia, bastante próxima de Delos. Em 2019, participei de escavações arqueológicas naquela ilha, uma iniciativa da Eforia das Cíclades com participação de arqueólogos gregos, da EfA e alguns outros que trabalham no projeto de topografia de Pompeia. Um dos grandes problemas relacionados a essa escavação, já que não há serviço regular de transporte até Reneia. Dessa forma, foi necessário contratar um serviço relativamente caro de transporte dos pesquisadores de Delos para Reneia diariamente. 
Outra questão específica própria de ambiente insulares como Delos é o processo ligado à preservação dos vestígios arqueológicos, já que esses são ambientes amplamente afetados pela umidade marinha. Se boa parte dos objetos de menores e médias dimensões foram preservados no interior do museu local, há vários elementos, sobretudo ruínas arquitetônicas, que permanecem no sítio arqueológico e que sofrem a ação da umidade marinha. Essas são questões fundamentais para se pensar na preservação dos monumentos que permanecem no sítio arqueológico.

Em Delos, nas zonas mais próximas do litoral, o mar avança e interfere diretamente na estabilidade de algumas estruturas. Por fim, ainda, é possível observar que, nesse ambiente, várias das estruturas estão submersas, o que indica a mudança dos limites do litoral ao longo do tempo. Nesse caso, são propostas algumas atividades de pesquisa que visam reconhecer e, ainda, recuperar alguns dos vestígios ali encontrados, no campo que se convencionou chamar "arqueologia subaquática". 


\section{REFERÊNCIAS BIBLIOGRÁFICAS}

Alroth, Brita. Greek gods and figurines: aspects of the anthropomorphic dedications. Uppsala: Almqvist and Wiksell distributors, 1989.

Bruneau, Philippe. Recherches sur les cultes de Délos a l'époque hellénistique et a l'époque imperiale. Paris : De Boccard, 1970.

Bruneau, Philippe. Les Mosaïques. Exploration Archéologique de Délos, 29, Athènes; Paris: École française d'Athènes; De Boccard, 1972.

Bruneau, Philippe; Ducat, Jean (ed.). Guide de Délos. Athènes: École Française d'Athènes; De Boccard, 2005.

Daux, Georges. Chronique des fouilles. Bulletin de Correspondance Hellénique, 83, livraison 2, 1959. p. 787-790.

Daux, Georges. Terrasse de 1'Héraion. Chronique des fouilles et découvertes archéologiques en Grèce en 1964. Bulletin de Correspondance Hellénique, 89, p. 996-9.

Déonna. Waldemar. Le mobilier délien. Exploration Archéologique de Délos, 18, Athènes; Paris: École française d'Athènes; De Boccard, 1938.

Dugas, Charles. Un trésor céramique à Délos. La révue de l'art ancien et moderne, 1912, 1, p. $339-352$

Dugas, Charles. Les vases de l'Héraion. Exploration Archéologique de Délos, X. Athènes: École Française d'Athènes; Paris: De Boccard, 1928.

Fraisse, Philippe; LLINAS, Christian. Documents d'architecture hellénique et hellénistique. Exploration Archéologique de Délos, 36. Athènes; Paris: Ecole française d'Athènes; De Boccard, 1995.

Hermary, Antoine. Sculptures archaïques de Délos : deux lions, une sirène et deux oiseaux. Bulletin de correspondance hellénique, 144.1. http://journals.openedition.org/bch/1045 (versão online consultada em 03 de jneiro de 2022).

Laumonier, Alfred. Les figurines de terre cuite. Exploration Archéologique de Délos, 23, Athènes; Paris: Ecole française d'Athènes; De Boccard, 1956.

Lévêque, Pierre. Héra et le lion, d'après les statuettes de Délos. Bulletin de Correspondance Hellénique, 73. 1949, p. 125-32.

Pirenne-Delforge, Vinciane. Héra, Apollon et l'Héraion de Délos à la période archaïque. In: Ainian, Alexander Mazarakis (org.) Les sanctuaires archaïques des Cyclades. Rennes: Presses Universitaires de Rennes, 2017, p. 91-104. 
Plassart, Andre. Les sanctuaires et les cultes du Mont Cynthe. Exploration Archéologique de Délos, XI. Athènes; Paris: Ecole française d'Athènes; De Boccard, 1928.

Prost, Francis. Origines du Sanctuaire d'Apollon. In: Étienne, Roland. (org.) Le sanctuaire d'Apollon à Délos. Exploration Archéologique de Délos, 44. Athènes; Paris: École française d'Athènes; De Boccard, 2018, p. 155-75.

Sarian, Haiganuch. Análises físico-químicas na determinação das origens da cerâmica orientalizaste das Cíclades da Grécia de Leste (sécs. VII e VI a.C.). Revista do Museu de Arqueologia e Etnologia, São Paulo, Supl. 2, 1997, p. 61-71.

Sarian, Haiganuch. Alguns dados relativos ao projeto de pesquisa "Arqueologia de um santuário: o Heraion de Delos, Grécia”. Revista do Museu de Arqueologia e Etnologia da USP, n. 10, p. 329-336, 2000. 